$$
\text { العدد: الرابع (أكتوبر (الأول). }
$$

\title{
International Journal of Research and Studies
}

$$
\text { والإستشارات والتنمية البشرية للتمدية }
$$




$$
\text { المجلة الدولية للبحوث والدراسات (IJS). }
$$

International Journal of Research and Studies

مجلة دورية علمية محكمة متخصصة.

تصدرها أكاديمية رواد التميز للتدريب والاستشارات والتنمية البشرية.

Pioneers of Excellence Academy for Training, Consulting and Human Development.

$$
\begin{aligned}
& \text { رئيس التحرير. } \\
& \text { أ.د. نجوى يوسف جمال الدين. } \\
& \text { أستاذ متفرغ بقسم أصول التربية. } \\
& \text { وكيل الكلية لشئون خدمة المجتمع وتنمية البيئة سابقاً. } \\
& \text { كلية الدراسات العليا للتربية، جامعة القاهرة. } \\
& \text { مدير التحرير - مar } \\
& \text { نائب رئيس التحرير - } \\
& \text { أ.م.د. محمود عبد المجيد رشيد عساف. أ.م.د. ممدوح عواد مفلح العنزي. } \\
& \text { أستاذ الادارة والتخطيط التربوي المساعد. أستاذ أصول التربية المساعد. }
\end{aligned}
$$

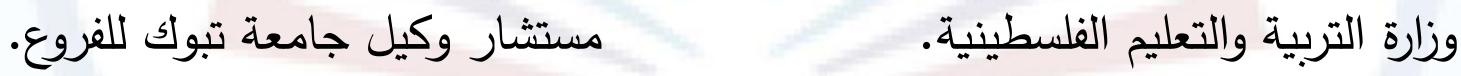

$$
\begin{aligned}
& \text { رئيس مجلس الإدارة. } \\
& \text { أ.م.د. أسامة عبد الغفار الثريف. } \\
& \text { أستاذ الإدارة التربوية المساعد، جامعة تبوك والملك سعود وطيبة سابقاً. } \\
& \text { عميد الأكاديمية، ورئيس مجلس الإدارة. } \\
& \text { أكتوبر } 2019 \\
& \text { العدد: (الرابع) (- (الع) }
\end{aligned}
$$

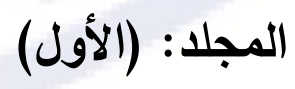




\section{المجلة الدولية للبحوث والاراسات (IJS).}

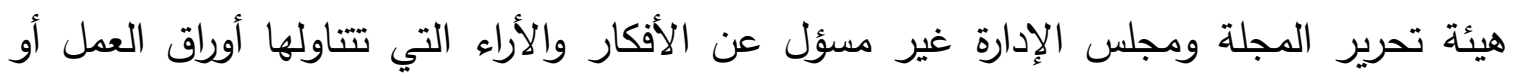

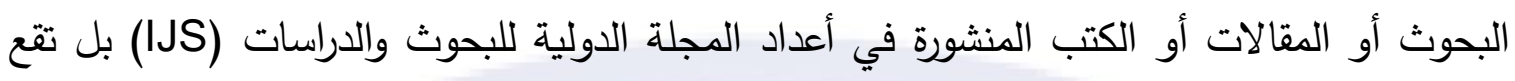

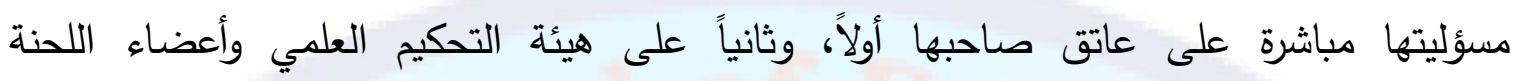
الاستشارية بالمجلة، وثالثاً تُعبر المواد المقدمة للنشر بالمجلة عن آراء ولثاء ونتائج واستنتاجات مؤلفيها

فقط.

لا تتشر المواد إلا بعد التحكيم وقبولها للنشر • الباحث مسؤول بالكامل عن صحة النقل من المراجع المستخدمة كما أن هيئة تحرير المجلة غير

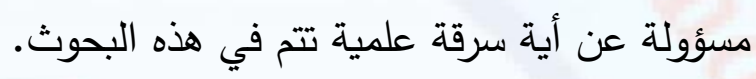

وتُعد المجلة الدولية للبحوث والدراسات (IJS) مجلة (دورية ـ علمية ـ محكمة) تصدرعن أكاديمية رواد التميز للتدريب والاستشارات، ربع سنوية، تصدر في (يناير - أبريل - يوليو - أكتوبر) والتي تعنى بنشر البحوث في المجالات التربوية والتعليمية، وتهدف المجلة إلى إتاحة الفرصة للباحثين في جميع بلدان العالم لنشر إنتاجهم العلمي الذي يتصف بالأصالة والجدة في مجال التعليم، ونشر نتائج دراساتهم التي لم يسبق نشرها. علاوة على السعي الدائم والعمل الدؤب لإيصالها للمهتمين والمختصين في مصر وربوع الوطن العربي مع الالتزام بأخلاقيات البحث العلمي، والمنهجية العلمية.

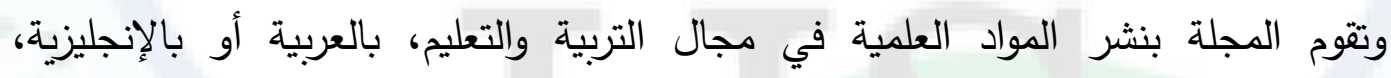
والفرنسية، أو أية لغة أخرى، وتثمل: (البحوث التربوية النظرية أوالتطبيقية الميدانية، والمراجعات

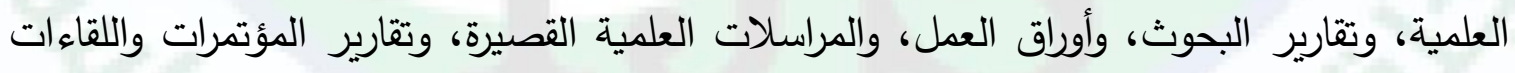

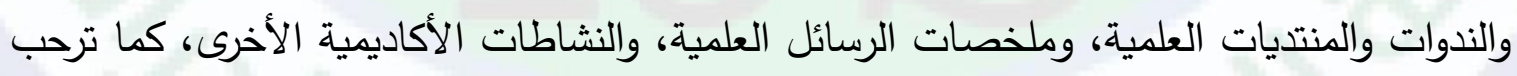
المجلة بنشر عروض الكتب المنشورة حديثًا في مجال المجلة). 


\section{ألمبأد:(الأول) العدد:(الرابع) أكثوبر}

الرؤية والرسائة والثهاف: تتبلور رؤية ورسالة وهدف المجلة الدولية للبحوث والدرسات (IJS) فيما يلي:-

بفضل من الله وعونـه استطاعت المجلة الدولية للبحوث والدرسات (IJS) في أعدادها الأولى منذ (2019م 1440هـ) أن تحققق رؤيتها ورسالتها وهدقها، وأن تقفز قفزات نوعية وجذريـة في تحقيق معايير وضوابط المجلة العلمية الرصينة، وقد سعت - منذ الوهلة الأولى، أن يكون لديها: 1. هيئة استثارية دولية من جمهورية مصر العربية، ومن مختلف البلدان العربية الثقيقية، وفي مختلف تخصصات العلوم التربوية والإنسانية. 2. هيئة محررين دوليين مـن جمهوريـة مصـر العربيـة، ومـن مختلف البلدان العربيـة الشتقيقية، ومختلف تخصصات العلوم التربوية والإنسانية. 3. تتوع دولي في المحكمين من جمهوريـة مصر العربية، والسعودية والأردن وفلسطين والعراق، ومعظم الدول العربية الثقيقة. 4. تنوع دولي في الباحثين من من جمهورية مصر العربية ومن خارجها. 5. قواعد نشر محررة ودقيقة وفق معايير وضوابط علمية محكمة. 6. يوجد ملخص للبحث باللغـة الإنجليزيـة (Abstract) وكلمـات مفتاحيـة دالـة للبحث .(Keyword)

7. انتظام في النشر ، تصدرأربع مرات في السنة في شهر (يناير ـ أبريل ـ يوليو - أكتوبر) علاوة على إصدارالأعداد المختلفة للمجلة في الوقت المحدد لها دون أي تأخير. 8. تنوع في نوعية البحوث التربوية وكافة العلوم الإنسانية المنشورة. 9. التزام المجلة أعلى معايير الجودة والاتقان والمضمون من حيث التحكيم والنشر . 10. معظم تعـاملات المجلـة إلكترونيـة، ومنها تقديم أوراق العم، والأبحـاث إلكترونياً مـن قبل فيل الباحثين، وأن تكون المجلة متاحة على شبكة الإنترنت، وتوافر المحتوى إلكترونياً على موقع 
11. نسعى دائما للعمل على تجويد وتحسين المجلة، بحيث نركز على جمال الإخراج، وجودة التنسيق، وتطوير شكل المجلة الخارجي والداخلي باستمرار .

$$
\text { الرؤيةة: تكمن رؤية المجلة الدولية للبحوث والدراسات (IJS) فيما يلي: }
$$

أن تكون المجلة الدولية للبحوث والدراسات (IJS) واحدة من أفضل المجلات العالمية المشهود لها بالأصالة والسبق في تكوين المعرفة والأفكار المستحدثة لتطوير التعليم والرقي، وأن تكون مجلة رائدة ومصنفة ضـمن أشـهر القواعد العالميـة في نشـر البحوث المحكمة في العلوم التربويـة والتعليميـة لتصبح مصدر معرفة ذات قيمة علمية تفيد المجتمع. الرسالة: تكمن رسالة المجلة الدولية للبحوث والدراسات (IJS) فيما يلي:

التميز في تقديم المقالات والبحوث العلمية ذو القيمة المضافة في مجال التعليم؛ والمحكمة بواسطة نخبة من العلماء والمتخصصين لتطوير جميع عناصر العملية التعليمية، والإسهام في إخراج بحوث علميـة متميزة، ومقابلة احتياجات الطلاب والباحثين وجميع أفراد المجتمع على مستوى المحلي والإقليمي والعالمي، وتتحقق رسالتنا من خلال الالتزام بالمعايير العالمية للتميز في مجالات التعليم والبحث العلمي وخدمة المجتمع.

الأهداف: تسعى المجلة الدولية للبحوث والدراسات (IJS) لتحقيق عدد من الأهداف، ومن أهها ما يلي:1. إيجاد وعاء نشر علمي أكاديمي متخصص في مجال التعليم للبحوث العلمية والمتميزة والمحكمة بواسطة نخبة من المختصصين. 2. أن تصبح المجلة مرجعًا علميًا للباحثين والدارسين في العلوم التربوية والتعليمية. 3. تلبية حاجة الباحثين على المستويات المحلية والإقليمية والعالمية في مجالات التربوية والتعليمية. 4. المشـاركة في بنـاء مجتمع المعرفة مـن خـلال نشر الأبحاث التربويـة التعليميـة الرصينة التي تساعد على تطوير المجتمع وتقدمه. 
5. رفـع القضـايا الهامـة في مجـال التعليم مــع تقديم بعض الحلـول المقترحـة للنهوض بالعمليـة

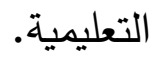

6. نشر ثقافة الفكر الإبداعي في جميع أنحاء العالم وخاصـة في الدول العربية؛ وذلك من أجل الارتقاء بمستوى التربية والتعليم والانتقال بها من الحيز الضيق للتعليم التقليدي إلى رحابة التعلم

$$
\text { والفكر الإبداعي. }
$$

أنشطة وخدمات المجلة الدولية للبحوث وإلدرسات (IJS) تقوم المجلة بتقديم الخدمات التالية: 1. - مثر البحوث، وأورلق العمل. 2. نشر ملخصات أطروحات الماجستير والاكتوراه.

$$
\text { 3. نشر الكتب والمقالات. }
$$

4. تحكيم أدوات الدراسة (الاستبيان، المقاييس، وغيرها).

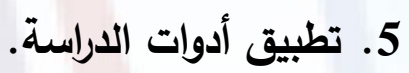
6. التحليل الإحصائي لأدوات الدراسة. 7. التدقيق اللغوي بالعربية والإنجليزية.

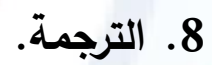


هيئة تحرير المجلة الدولية للبحوث والدراسات(IJS) International Journal of Research and Studies

\begin{tabular}{|c|c|c|}
\hline الصفة & المسمى الوظيفي & 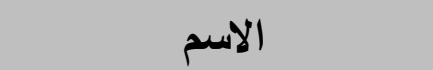 \\
\hline 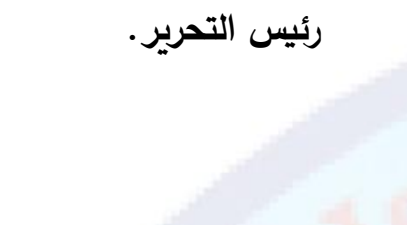 & أستاذ متقرغ بقسم أصسول التربية، وكيل الكلية لشـئون & نجوى يوسف جمال الدين \\
\hline نائب رئيس التحرير & والتعليم الفلسطينية. الادارة والتخطيط التربوي المساعد، وزارة التربية & عساف. أ.م.د. محمود عبد المجيا رشيد \\
\hline مدير التحرير & للفروع. & العنزي. \\
\hline عميل الأكاديمية، ورئيس & وطيبة سابقاً. & 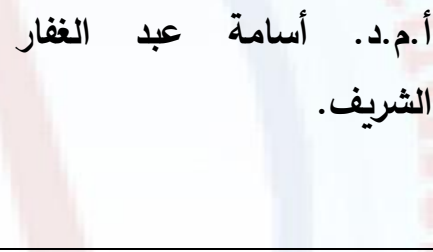 \\
\hline عضواً. & الستاذ ورئيس قسم التعليم العالي والتعلم المستمر كلية & أ.د. أسامة محمود فراج سيد. \\
\hline عضواً. & كولومبس أستاذ أمريكا. النفسية، خبير تنمية بشرية معتمد من جامعة & 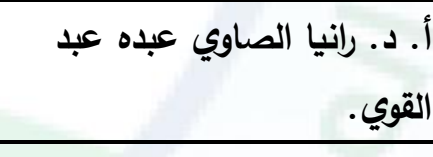 \\
\hline مدقق ومراجع لغوي. & دراسات عليا في اللغة العربية وآدابها. & أ.دعاء حسين محمل عباس. \\
\hline ع فني. & نائب مدير التحرير. & أحمدالد صلاح أبو هاشم \\
\hline إثراف عام. & أخصائي التطوير والتحسين بالبرامج التربوية. & نعينع أ.محم فتح الله فتح الله \\
\hline الإخراج والتنفيذ الفني. & مصمم مواقع. & 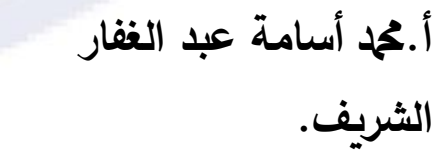 \\
\hline
\end{tabular}




\section{المجلد:(الأول) العدد:(الرابع) أكتوبر2019}

جهود هيئة تحرير المجلة الدولية للبحوث والدراسات (IJS) في الارتقاء بمستوى تحكيم البحوث. 1. تخضـع عمليـة اختيـار المحكمين بالمجلـة الدوليـة للبحوث والدراسـات (IJS) لآليات وضـوابط وشروط وضمن منهجية، فشخصية المحكم لا تقل أهمية عن علمه ومعرفته، فلا بد أن يكون مشهوداً لهذه الثخصية بالحياد وسعة الأفق والابتعاد عن الجوانب الثخصية (قدر المستطاع). 2. السعي الدؤب للارتقاء بمستوى نظام التحكيم العلمي. 3. تم تأسيس لجنة علمية من الخبراء في مجال التحكيم العلمي، تتولى وضع المعائير التهير اللازمة.

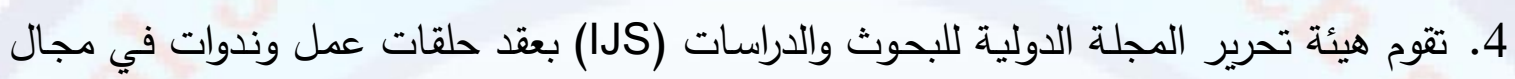

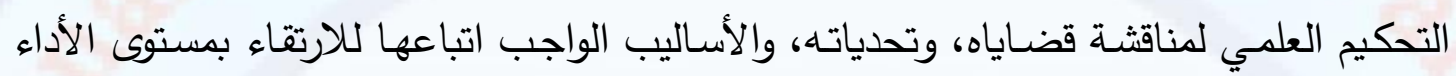

$$
\text { التحكيمي لاى أطراف عملية التحكيم. }
$$

5. تسعى هيئة تحرير المجلة الدولية للبحوث والدراسات (IJS) نحو عقد دورات تدريبية وتنظيم ورش عمل للمحكمين غير المتمرسبن لبناء القدرات التحكيمية، عن طريق إعداد وتأهيل المحكم العلمي وفق القواعد والمعايير المطلوبة للارتقاء بجودة البحث العلمي.

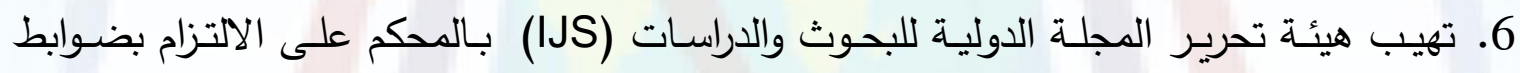

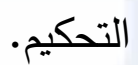


المباد:(الأول) العدد:(الرابع) أكثوبر 2019

الهيئة العلمية الاستشارية للمجلة الدولية للبحوث والدراسات(IJS)

\begin{tabular}{|c|c|c|c|}
\hline 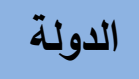 & 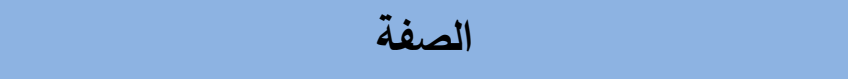 & 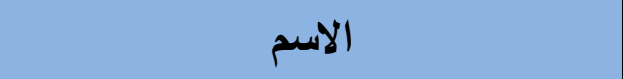 & \\
\hline مصر · & رلائيس قسم المجالات بكلية الخدمة الاجتماعية جامعة & & 1 \\
\hline & 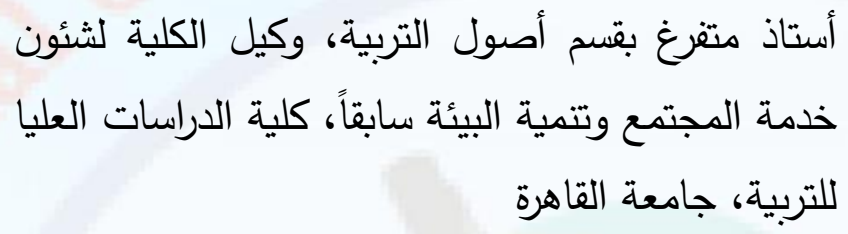 & 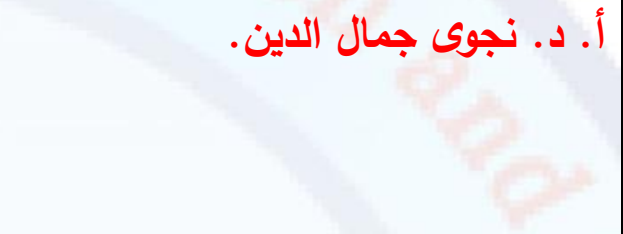 & 2 \\
\hline مصر . & كلية التربية، جامعة بني سويف. & |أ.د. أحمد عحما غانم. & 3 \\
\hline مصر • & الكبار أستاذ ورئيس قسم التعليم العالي والتعلم المستمر كلية & | أ.د. أسامة محمود فراج سيد. & 4 \\
\hline مصر - ا. & أستربية أصول التربية والتخطيط التربوي و وكيل كلية & |أ.د. جمعه سعيا تهامي. & 5 \\
\hline 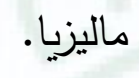 & كلية التربية، جامعة المدينة العالمية. & |أ.م.د. إيمان تحمل مبروك. & 6 \\
\hline 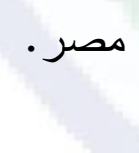 & كعتية التربية، جامعة الزقازيق، مدرب تتمية بشرية & أ.م.د. إبراهيم رمضان هنداوي فضيلة. & 7 \\
\hline مصر. - مص & كلية التربية، جامعة 6 أكتوبر • & |أ.م.د. أمين عحمل محمد أبو بكر. & 8 \\
\hline 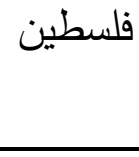 & والتتعليم اللفسطينية. والتخطيط التربوي المساعد، وزارة التربية & عساف. & 9 \\
\hline 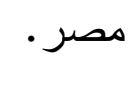 & 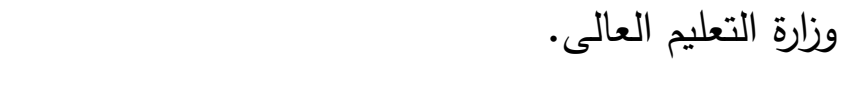 & |أ.م.د. عبدالله عاصم غازي. & 10 \\
\hline
\end{tabular}

International Journal of Research and Studies (ijs) It is issued by the Excellence Pioneers Academy 


\begin{tabular}{|c|c|c|c|}
\hline السعودية. & تبتوك سابقاً، خبيرة التربية الخاصة المساعد، كلية التربية، جامعة الخاصـة ومدربة تتمية بشرية. & أ.م.د.سحر عبد الفتاح خير الله عبد & 11 \\
\hline مصر. & خبير مناهج ومدرب مدرسين، وزارة التربية والتعليم & سميرة بكر . & 12 \\
\hline يلة. & محاضر و ومنسق مقرر مهارات أكاديمية وحياتية، & & 13 \\
\hline 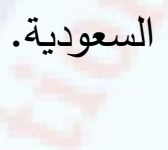 & تبوكتاذ أصول التربية المساعد، ومستشار وكيل جامعة & أ.م.د. ممدوح عواد مفلح العنزي. & 14 \\
\hline 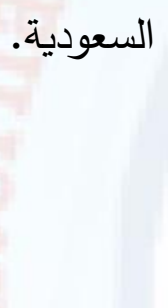 & أستاذ الصحة النفسية، كلية التربية، جامعة القصيم، & أ. د. رانيا الصاوي عبده عبد القوي. & 15 \\
\hline & أستاذ أصول التربية المساعد، كلية التربية، جامعة & .1 & 16 \\
\hline & دكتوراه صحة نفسية و وإرشاد نفسية، كلية الآداب & د. رشيا عحمد أحمد خ & 17 \\
\hline 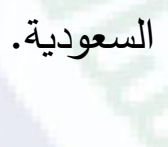 & أستاذ أصول التربية المساعد، كلية التربية، جامعة أم & أ.م.د. خالا عبدالرحمن ياسين أحمد. & 18 \\
\hline مصر. & المعهد العالي للعلوم التجارية والحاسب الآلي بالعريش. & أ.د.السيد عبد المنعم علي متولي & 20 \\
\hline مصر . & أستاذ الكمياء النووية، كليه العلوم، جامعه حلوان. & أ.د. عبدالحكيم طه قنديل. & 21 \\
\hline مصر. & مدير مركز تعليم الكبار، جامعة عين شمس، مدرس التربية، كلية التربية، جامعة عين شمس. & أ.م.د. إسلام عحمد السعيد. & 22 \\
\hline مصر · & 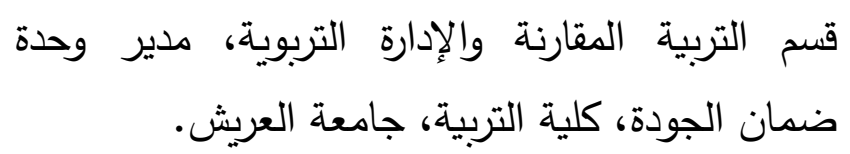 & أ.م.د.عبد الكريم ححمد أحمد حسين. & 23 \\
\hline
\end{tabular}

\section{International Journal of Research and Studies (ijs)




\begin{tabular}{|c|c|c|c|}
\hline 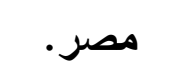 & كلية الطفولة المبكرة، جامعة الإسكندرية. & أ.م.د. سحر فتحي إبراهيم حجازي. & 24 \\
\hline 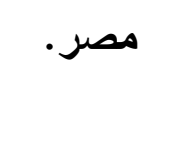 & كلية التربية، جامعة الفيوم. المناهج وطرق تدريس اللغة الفرنسية المساعد، & | أ.م.د.عبد الناصر | & 25 \\
\hline 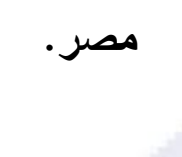 & 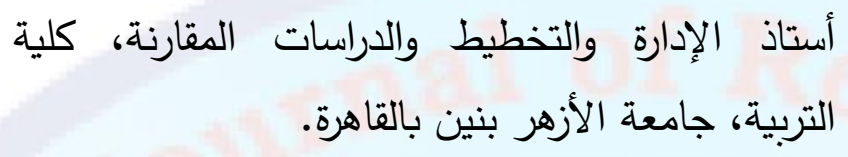 & |أ.د. محمث يوسف مر & 26 \\
\hline 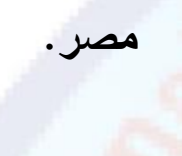 & أستاذ مساعد، كلية التربية، جامعة تبوك، سابقاً & أ.م.د. هدى عبد الد & 27 \\
\hline 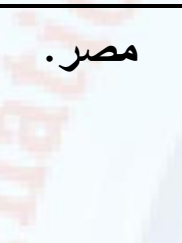 & 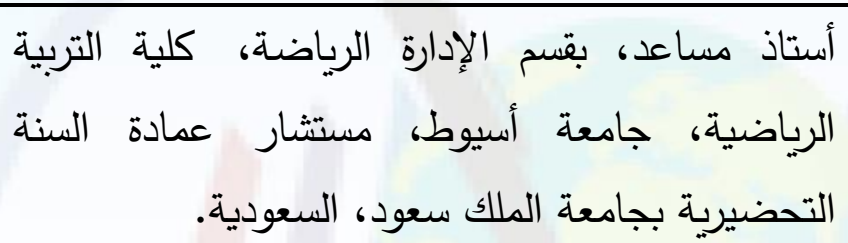 & |أ.م.د. محمود صديق عبدالواحد سعد. & 28 \\
\hline 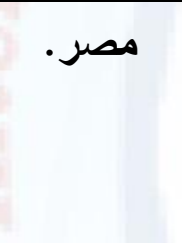 & وأستاذ المناهج وطرق تدريس الدراسات الاجتماعية، & أ.ـد. فايزة أحمد الد & 29 \\
\hline 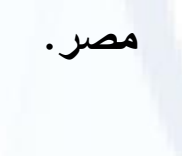 & المنيا. & | د.إيمان عاشور سي & 30 \\
\hline 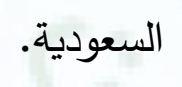 & كلية التربية، جامعة المدينة العالمية، ماليزيا. & |د.عبدالكريم صديق البرناوي. & 31 \\
\hline 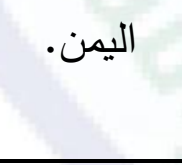 & رائيس مجلس الإدارة بمركز أمارجي الدولي للتنمية & 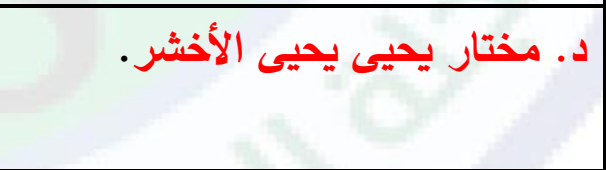 & 32 \\
\hline 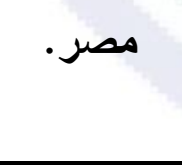 & 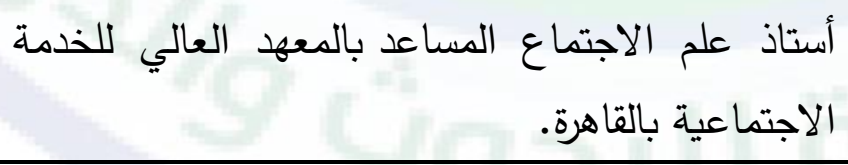 & أ.د & 33 \\
\hline مصر. & مدرس علم الاجتماع بكليه التربيه، جامعه عين شمس. & لد. رباب جلال محمد البصراتي. & 34 \\
\hline 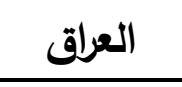 & كلية التربية ابن رشد للعلوم الإنسانية، جامعة بغداد. & أ.م.د. علي عطيه عذاب العتابي. & 35 \\
\hline 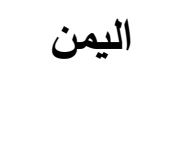 & صنعاء. أستاذ إدارة التعليم العالي المساعد، كلية التربية، جامعة & |د. خليل محمد مطهر الخطيب. & 36 \\
\hline
\end{tabular}




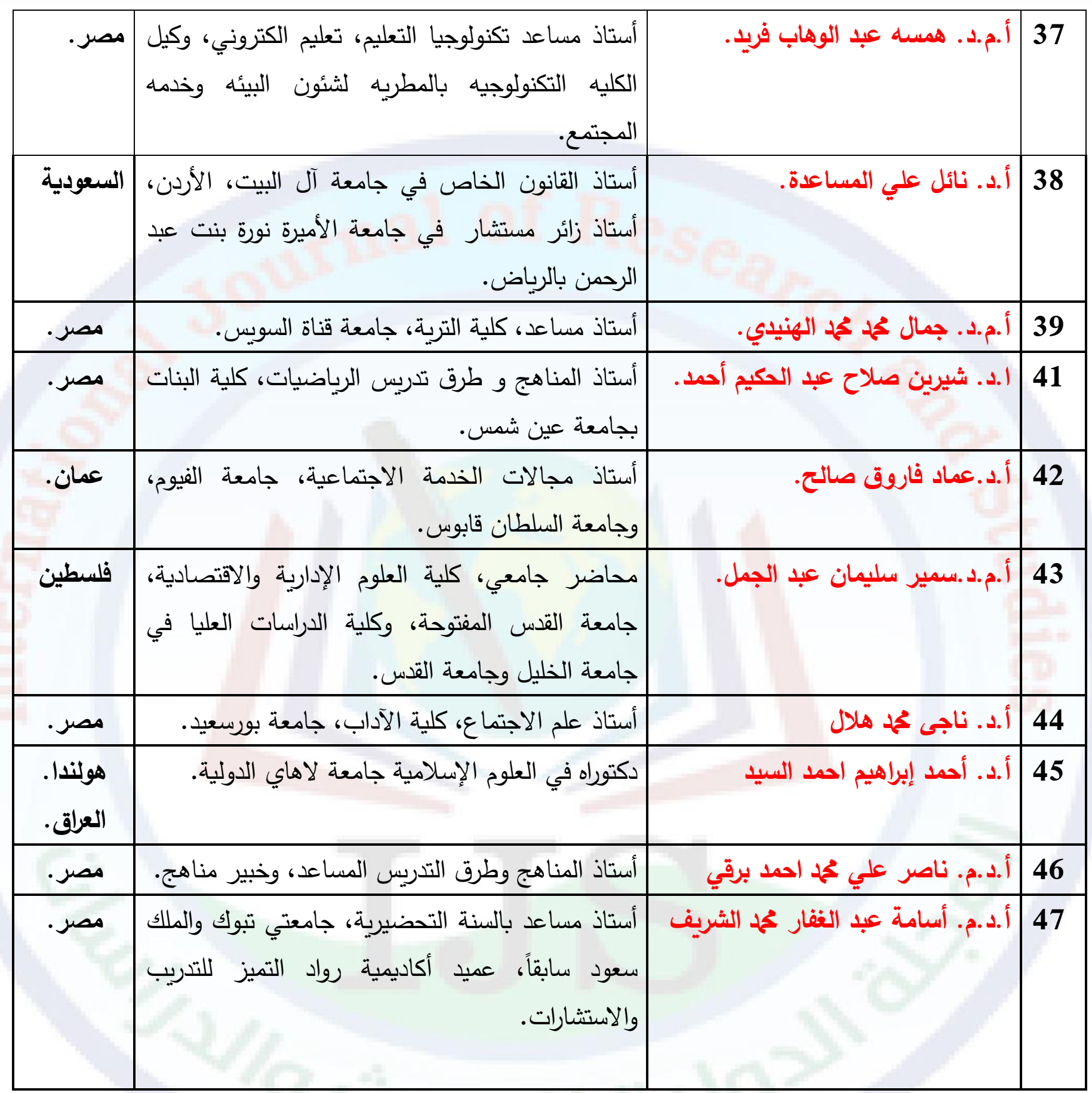


قواعد النشر بالمجلة الدولية للبحوث والدراسات (IJS): يشترط فيما يقدم للنشر في المجلة الآتي: 1. أن تكون البحوث والدراسات المقدمة للمجلة أصلية ومبتكرة في مجال تطوير وإصلاح منظومة

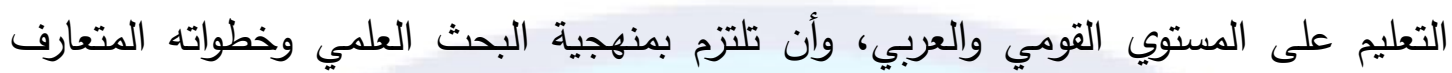
عليها.

2. تكتب البحوث باللغة العربية أو الإنجليزية، أو الفرنسية، أو أية لغة أخرى.

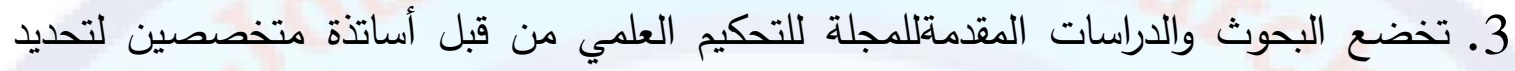
مدى صلاحيتها للنشر ، وذلك وفقاً لنموذج تحكيم محكم ودقيق.

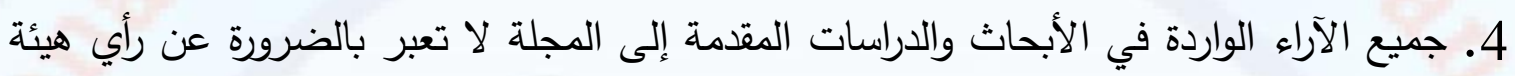
التحرير ، أو الهيئة الاستشارية ، بل تعبر عن رأي أصحابها.

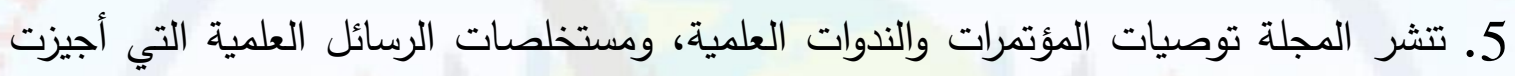
مناقتشها والكتب النادرة، وكذلك التقارير العلمية، والترجمات. 6. تتشر البحوث والدراسات المقدمة حسب أسبقية ورودها إلى المجلة بعد تحكيمها وقبولها للنشر ولثرات ولثرات واستيفاء رسوم النشر المقرة. 7. ترتيب البحوث والدراسات في المجلة يخضع لقواعد تنظيمية خاصة، ولا علاقة لها بأهمية البحث أو مكانة الباحث. تُش الجوث

الشروط الفنية للنشر بالمجلة الدولية للبحوث والدراسات (IJS): يجب توافر الثروط الفنية التالية عند تسليم البحث: 1. على الباحثين التأكد من سلامة لغة البحث، ومراعاة التدقيق اللغوي، وأن تخلو أبحاثهم من الأخطاء اللغوية والنحوية. 2. أن يكون نوع الخط في المتن كما يلي: • للبحوث العربية تكتب علي برنامج "Word" باستخدام خط Simplified Arabic بحجم (14) والعناوين الرئيسة بحجم (14) غامق، والعناوين الفرعية بحجم (14) بولد، وأن يكون نوع الخط في الجداول للبحوث العربية Simplified Arabic بحجم (10) • 


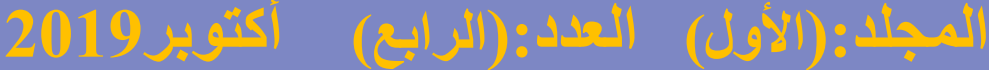

•لبحوث الإنجليزبة تكتب علي برنامج "Word" باستخدام خط Time New Romans بحجم

(14) والعناوين الرئيسة بحجم (14) غامق، والعناوين الفرعية بحجم (14) غامق، وأن يكون

نوع الخط في الجداول للبحوث الإنجليزية Time New Romans بحجم (12).

الهوامش حجم الواحد منها (2سم يمين ويسار الصفحة) (3سم أعلى وأسفل الصفحة) وتباعد

السطور (1.5).

تستخدم الأرقام العربية 1، 2، 3 ...... في جميع ثنايا البحث، وأن يكون ترقيم صفحات

البحث في منتصف أسفل الصفحة.

يتم وضع الجداول والأشكال إما في صفحات منفصلة أو وسط النص وفقا لرؤية الباحث. 3. لا تزيد كلمات ملخص البحث عن (200) كلمة، ويشترط في البحث المقدم بلغة أجنبية أن يدرج فيه ملخص باللغة العربية.

4. أن لا يزيد عدد صفحات البحث عن 30 صفحة (8000 كلمة) بما في ذلك الملخصين (ملخص البحث باللغة العربية، واللغة الانجليزية) والكلمات المفتاحية، الجداول، والأشكال، والمراجع، والملاحق والاقتصار على أقل عدد من الجداول.

5. أن يكتب عنوان البحث، واسم الباحث- الباحثين، والجامعة- المؤسسة التي ينتمي إليها، على صفحة مستقلة قبل صفحات البحث، ثم تتبع بصفحات البحث. 6. أن يتكون البحث من العناصر التالية:

ملخص للبحث، المقدمة والخلفية النظرية، مشكلة الدراسة وأسئلتها - فرضياتها، ثم أهدافها، ثم أهمية الدراسة، ثم محددات الدراسة، ثم مصطلحات الدراسة، الإطار النظري والدراسات السابقة، ثم الطريقة وإجراءات الدراسة: وتتضمن (منهج الدراسة، والعينة، وأدوات الدراسة، الخصائص السيكومترية لأدوات الدراسة (الصدق والثبات، وإجراءات الدراسة، والأساليب الإحصائية). ثم نتائج الدراسة ومناقشتها: ويشتمل هذا القسم على نتائج التحليل والجداول والأشكال والتعليق عليها، ثم التوصيات المنبثقة عنها، وأخيراً توضع قائمة المراجع، مرتبة أبجدياً، 


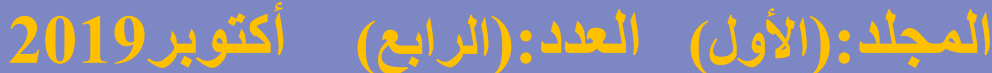

7. تدرج الجداول في النص وترقم ترقيماً متسلسلاً وتكتب عناوينها فوقها، أما الملاحظات

التوضيحية فتكتب تحت الجدول.

8. تذكر الهوامش وملاحظات وتوضيحات الباحث في آخر الصفحة عند الضرورة.

9. لهيئة التحرير حق الفحص الأولي للبحث، وتقرير أهليته، أو رفضه للنشر.

10. في حالة قبول البحث للنشر تؤول كل حقوق النشر للمجلة، ولا يجوز نشره في أي منفذ

نشر آخر ورقيًا أو الكترونيًا، دون أذن كتابي من رئيس هيئة التحرير .

11. م تقديم البحوث إلكترونياً من خلال بريد المجلة الإلكتروني، أو موقغها الإلكتروني.

12. يحق للباحث - إذا ما رغب - الحصول على نسحة ورقية من أعداد المجلة، أو مستلة

بحثه، وذلك بعد سداد الرسوم المطلوبة لطباعة العدد أو المستله.

13. يتم تقديم البحوث الكترونيًا على برنامج Word من خلال البريد الإكتروني المجلة،

والتواصل عبر الأرقام التالية:-

للتو اصل: ميل: osama.elshrief@yahoo.com

فون وواتس:(0096656380991) - 00201090854422011 50977347 


\section{القواعد المنظمة للنشر المجلة الدولية للبحوث والدراسات (IJS).}

تقوم المجلة الدولية للبحوث والدراسات (IJS) بنشرالبحوث العلمية التي تتوافر فيها الأصالة والمنهجية العلمية ويتوافر فيها مقومات ومعايير إعداد مخطوط البحث، مع الالتزام بأصول البحث العلمي وقواعده العامة، ومراعاة التوثيق العلمي الدقيق لمواد البحث.

وأن يتسم البحث بالعمق والأصالة، والجودة في الفكرة والأسلوب والمنهج، والتوثيق العلمي، والخلو من الأخطاء اللغوية والنحوية، الإسهام في تتمية الفكر التربوي وتطبيقاته محلياً أو عربياً أو عالمياً، بناء على القواعد المنظمة للنشر المجلة الدولية للبحوث والدراسات (IJS) وهي كما يلي:

1. تعنى المجلة بنشر البحوث العلمية المقدمة إليها في مجالات العلوم التربوية، والعلوم الإنسانية 2. تعتذر المجلة عن عدم النظر في البحوث المخالفة للتعليمات وقواعد النشر المدونة على موقع المجلة، وفي أعددادها التي تم نشرها. 3. التعهد: على الباحث أن يوقع - بخط اليد - (نموذج التعهد) يؤكد أن البحث لم ينشر ، أو لم يتقدم لنشر بحثه في مجلة علمية أخرى، وأن بحثه لم يسبق نشره، ورقياً أو إلكترونياً، وأنه لن يُنشر في أية مجلة، أو كتاب قبل أن يبلّغ برد المجلة وحكمها، علاوة تدوين معلومات مختصرة

$$
\text { عن: (عنوانه - تخصصه - بريده الالكتروني - رقم الهاتف). }
$$

4. تتظيم كتابة البحث وطباعته على أساس كتابة العناوين الرئيسة وسط السطر والعناوين الفرعية في الجانب الأيمن في سطر مستقل والعناصر الثانوية في بداية الفقرة. 5. إرسال نسخة إلكترونية بصيغة الوورد، مع إرسال السيرة الذاتية للباحث، إن كانت مراسلته المجلة

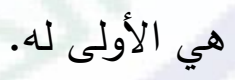

6. ينبغي الالتزام بالعناصر الواجب توافرها في البحث وبشكل متسلسل وهي: > العنوان: لابد أن يكون واضح ومحدد ولا يتعدى ثلاثة عشر كلمة. > المقدمة: في حدود صفحتين، أو ثلاثة بحيث تبدأ من العام إلى الخاص، وتوضح أهمية البحث. 


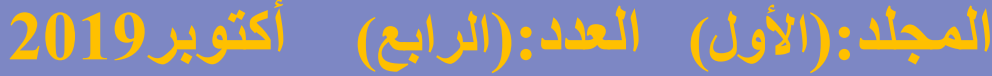

> الإطار النظري للبحث: ويشمل: (مشكلة الدراسة، وتساؤلاتها، وأهداف الدراسة، وأهمية الدراسة، ومنهج الدراسة، وحدود الدواسة، ومصطلحات الدراسة).

> منهج البحث: يبين عينة البحث وخصائصها وكيفية اختيارها وحدودها وأدوات البحث ومعاملات ثباتها وصدقها وإجراءات تطبيقها وتصحيحها وإجراءات السير في البحث والأساليب الإحصائية

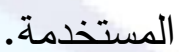

وتقوم هيئة تحرير المجلة بمراجعة البحوث التي تصلها من الناحية الأولية وتتأكد من أن البحث يتوفر فيه الثروط الأساسية للنشر، فإدا توفرت ترسلها إلى المحكمين، وهذه الشروط كما يلي: • كتابة عنوان البحث واسم الباحث ولقبه العلمي والجهة التي يعمل لديها على الصفحة الأولى. عرض النتائج في جداول، وتحليلها، ومناقشتها، على أن تتضمن الجداول في حال استخدام اختبار ت: المتوسط والانحراف المعياري لكل مجموعة وقيم ت ودلالتها الإحصائية.

وفي حال استخدام كاي تربيع التكرارات في المجموعات ودرجات الحرية وقِيَم كاي تربيع ودلالتها الإحصائية.

وفي حال استخدام تحليل التباين: مجموع التباين بين المجموعات وفي داخل المجموعات وقيمة

$$
\text { ف ودرجات الحرية ودلالتها الإحصائية. }
$$

وفي حال النسب المئوية تذكر التكرارات والنسب المئوية لها.

وفي حال معاملات الارتباط يذكر عدد أفراد العينة ومعاملات الارتباط ودلالتها الإحصائية. الدراسات السابقة: يتم عرض خمس أو سبع دراسات حديثة ذات صلة وثيقة بالدراسة الحالية، منا دراسـات عربية، ودراسـات أجنبية، ثم التعليق على الدراسـات السابقة، ويشمل أوجه الثبه والاختلاف بين الدرسات السابقة والدراسة الحالية، وأوجه الاستفادة من الدراسات السابقة، وما يميز الدراسة الحالية عن الدراسات السابقة). > إجراءات الدراسـة الميدانيـة: وتتضـمن:(مجتمع الدراسـة، والعينـة، أفراد الدراسـة، أداة الدراسـة، إجراءات الدراسة، المنهج المستخدم). 


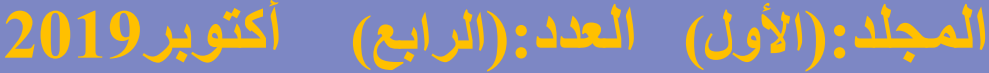

> مناقثة نتائج الدراسة النظرية والميدانية. > الاستتتاجات والتوصيات، والمقترحات.

> ملخص الدراسة: أن يرفق الباحث ملخصاً عن بحثه باللغة العربية والإنجليزيـة في حدود (200) كلمة ويحتوي على الهدف من الدراسـة ووسـائل وطرق البحث المستخدمة، ثم أهم النتائج التي توصـلت إليهـا الدراسـة، ويكون الملخص باللغـة الإنجليزيـة ترجمـة للملخص العربـي وبالثـروط ذاتها.

> التوثيق: سواء كانت المراجع العربية والأجنبية، يتبع نظام جمعية علم النفس الأمريكية (APA) ويتم أبجدتها.

التوثيق: تعتمد المجلة دليل(APA) (American Psychological Association) للنشر العلمي بشكل عام، تكتب جميع المراجع الوارد في متن البحث في قائمة المراجع، ويلتزم الباحث بقواعد الاقتباس والرجوع إلى المصادر الأولية، وأخلاقيات النشر العلمي، وتحتفظ المجلة بحقها في رفض البحث، والتعميم عن صاحبة في حالة السرقات العلمية. قائمة المراجع: يذكر فيها جميع المراجع التي أشير إليها في متن البحث وترتب ترتيباً هجائياً على حسب الاسم الأخير للباحث، وتأتي المراجع العربية، أولاً ثم المراجع الأجنبية بعدها، وتذكر بيانات كل مرجع على النحو الآتي:

1. عندما يكون المرجع كتاباً: اسم المؤلف (سنة النشر): عنوان الكتاب (الطبعة أو المجلد) اسم

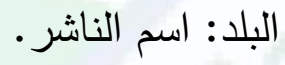

> مثال: أبو علام، رجاء محمود (11 (r): علم النفس التربوي، الكويت: دار القلم.

$>$. Bernstein, T. M. (2014). The careful writer: A modren guide to English usage. New York: Athencum.

2. عندما يكون المرجـع بحثاً في مجلـة علمية: اسم الباحث (سنة النشر): عنوان البحث، اسم المجلة، المجلد (الأول) العدد (الخامس) صفحات البحث في المجلة، مثلاً: ص ص:123- 


\section{المبأد:(الأول) العدد:(الرابع) أكتوبر}

> مثال: الثريف، حمح عبدالله (2020): دراسة تقويمية للدورة التدريبية لمنهج الرياضيات المطور والموحد للصف الثالث الابتدائي جمهورية مصر العربية. مجلة البحوث التربوية، العدد: (Yr)

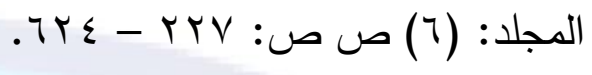

$>$ Luft, J. (1999). Teachers' salient beliefs about a problem solving demonstration classroom in-service program. Journal of Research in Science Teaching, 36(2), 141-158.

عندما يكون المرجع بحثاً في كتاب: اسم الباحث (سنة النشر): عنوان البحث في: اسم معد الكتاب، عنوان الكتاب، اسم البلد: الناشر، الصفحات التي شغلها البحث.

وتؤكد المراجع صدق الباحث، وتعد دليل على رصـانة البحث العلمية، ومن ثم يجب أن تكون أصيلة وصحيحة وسليمة في صياغتها، وعلى الباحثين الالتزام بضوابط الصياغة التي حددتها رابطة علم النفس الأمريكية APA في دليلها؛ من حيث: صحة الأسماء والمصادر، تسلسل البيانات، علامات الترقيم، والترتيب الهجائي للأسماء، وأن تحتوي قائمة المراجع على كل المراجع الواردة في متن تقرير الدراسة بلا زيادة أو نقصان.

وتكون الإثارة إلى المراجع في متن التقرير بذكر الاسم الأخير للمؤلف أو الباحث وسنة النشر بين قوسين، رقم الصفحة، مثل: (الشريف، rا • r، ص:45) أو (Garder, 2019) إذا كان الباحثون أكثر من اثثين وحتى خمسة يذكر الاسم الأخير لجميع الباحثين عند أول اقتباس ويليها سنة النشر، وإذا تكرر الاقتباس من نفس المصدر يذكر الاسم الأخير للباحث الأول وآخرون أو . et al. يليها

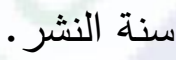

أما إذا كان الباحثون أكثر من خمسة فيذكر الاسم الأخير للباحث الأول وآخرون، ثم سنة النشر. وعند الاقتباس يوضع النص المقتبس بين قوسين صغيرين وتذكر أرقام الصفحات المقتبس منها. > الملاحق: أدوات الدراسة، جداول، إحصائيات، وغيرها إن وجد. 
7. تعرض البحوث المقدمة للنشر في المجلة - في حال قبولها مبدئياً - على محكمينْ اثنين في الأقل من ذوي الاختصاص يتم اختيارهما بسرية مطلقة. 8. تحتفظ المجلة الدولية للبحوث والدراسات (IJS) بحقها في أن تطلب من المؤلف أن يحذف أو يعيد صياغة بحثه أو أي جزء منه بما يتتاسب وسياستها في النشر وللمجلة إجراء أية تعديلات شكلية تتناسب وطبيعة المجلة.

9. تقوم المجلة بإبلاغ الباحث، أو الباحثين حال وصول البحث، وحال قبوله، أوعدم قبوله للنشر . 10. على الباحث أن يقدم نسخة من كل ملحق من ملاحق البحث (إن وجدت) مثل برمجيات، اختبارات، ...، وأن يتعهد خطياً بالمحافظة على حقوق الآخرين الفكرية (الملكية الفكرية). 11. لا تدفع المجلة مكافأة عن البحوث التي تتشر فيها. 12. تهدي المجلة لمؤلف البحث بعد نشره، نسخة إلكترونية من المجلة. 13. تنقل حقوق طبع البحث ونثره إلى المجلة الدوليـة للبحوث والدراسـات (IJS)عند إخطار صاحب البحث بقبول بحثه للنشر .

14. يوضح الباحث ما إذا كان البحث مستلاً من رسالة ماجستير ، أو أطروحة دكتوراة، وتوضيح ذلك في هامش صفحة العنوان، وتوثيقها توثيقاً كاملاً على نسخة واحدة من البحث يذكر فيها

$$
\text { اسم الباحث وعنوانه. }
$$

تؤكد هيئة تحرير المجلة الدولية للبحوث والدراسات (IJS) على أن ما يرد في هذه المجلة يعبر عن آراء المؤلفين ولا يعكس بالضرورة آراء هيئة التحرير ، أو مجلس الإدارة. إرسال خطاب عبر الميل أو الواتس، موجه لهيئة تحرير المجلة، يحتوى على: (طلب نشر البحث). للتو اصل: مبل: osama.elshrief@yahoo.com فون وواتس:(0096656380991 - 00201090854422-002011) 
الميثاق الأخلاقي لنشر البحوث بالمجلة.

تقوم المجلـة الدوليـة للبحوث والدراسـات (IJS) بنشـر البحوث العلميـة الرصينة والأصيلة والمحكمة من قبل أساتذة متخصصون، بهدف توفير ونشر وإصدار بحوث متميزة ذات جودة عالية، ولك من خلال الالتزام بمباديء وأخلاقيات البحث العلمي، حيث تسعى المحلة بوضع وتحديد معايير

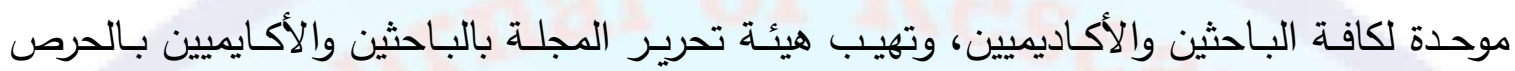
والالتزام بتطبيق أخلاقيات البحث العلمي، في إطار قبول المسؤلية والواجبات المنوطة بكل الأطراف. بهدف رفع الوعى المهنى، وترقية عملية البحث العلمي، والاستخدام الأخلاقي للمعلومات، بما يعني تطوير السياسات، والأدوات اللازمة لذلك، مع تقديم أفضل الخدمات للباحثين والأكاديميين والمجتمع، واحترام اللوائح، والنظم، والقوانين، والحرص التهات على تطبيقها، لضمان سير العمل، فى إطار أخلاقى متوازن.

تُولي المجلة الدوليـة للبحوث والدراسـات (IJS) أهميـة قصسوى للأمانـة العلميـة والأخـلاق،

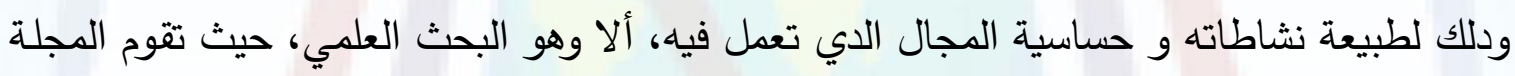
بالتسيير والتوجيه العلمي والإداري للمشاريع البحثية، وإدارة البيانات والموارد من أجل الإنتاج العلمي لإلهي

علاوة على تحسن قيمة نتائج البحوث العلمية، سواء على مستوى الاستفادة المباشرة أو عن

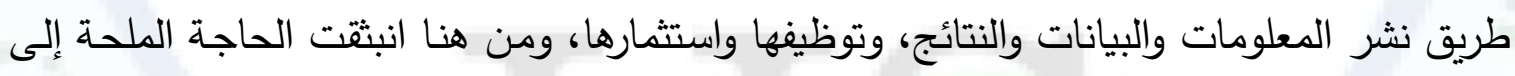

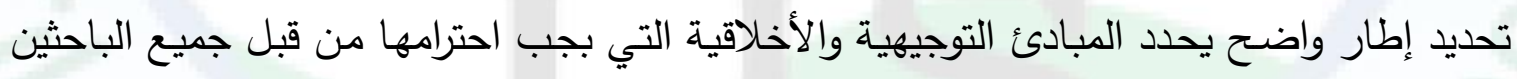
والأكاديميين، ودلك بهدف تشجيع تتمية البحث العلمي في مجال العلوم الإنسانية والتربوية والنفسية،

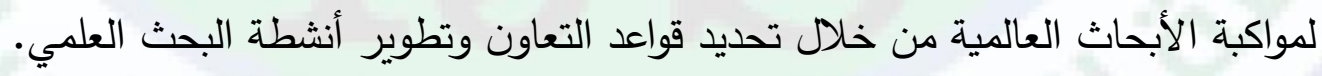

وفي هدا الإطار تحرص المجلة الدولية للبحوث والدراسات (IJS) على نهج سياسة تروم الحصول على إطار ونتائج بحثية عالية الجودة عن طريق احترام المعايير الأخلاقية والنزاهة العلمية،

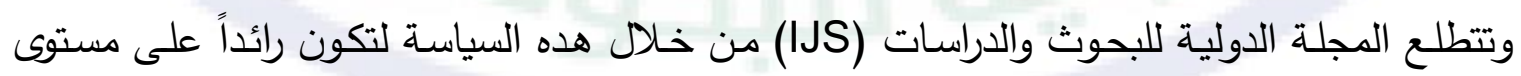

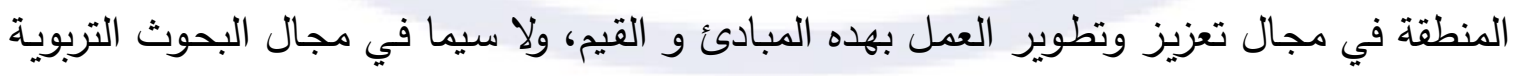

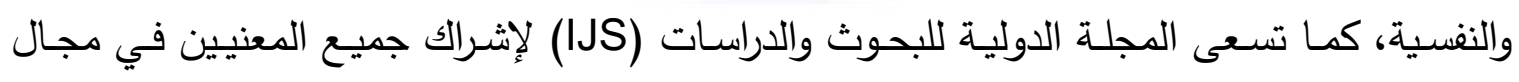
البحث العلمي من باحثين وعلماء في منطقة الثرق الأوسط في الالتزام بهده المبادئ. 
وتقوم المجلـة الدوليـة للبحوث والدراسـات (IJS) في هدا الإطـار باعتمـاد قواعد عالميـة في مجال الأخلاق والأمانة العلمية، ويتبع أفضل القواعد المعتمدة في هدا المجال على المستوى العلمي أولاً: ميثاق أخلاقيـات الأنثطة البحثية: تَحث المجلة الدولية للبحوث والدراسات (IJS) الباحثين

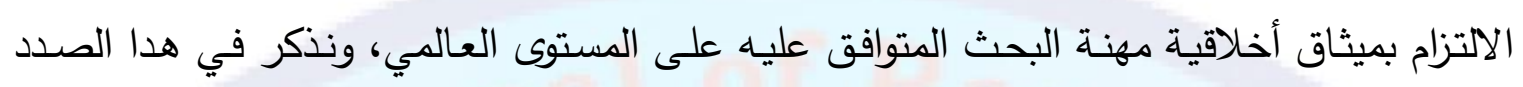

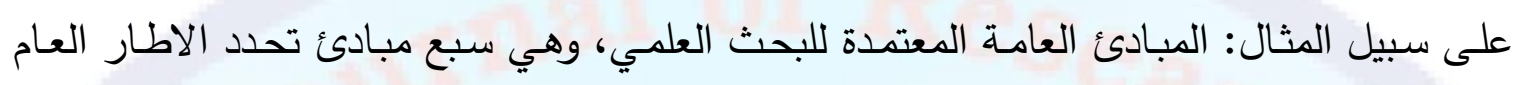
لأخلاقيات مهنة البحث العلمي، وهي كالتالي:1. الامتثال للتشريعات القانونية: يجب على كل باحث معرفة النصوص القانونية المنظمة للبحث العلمي، والحرص على احترامها والعمل بما جاء فيها.

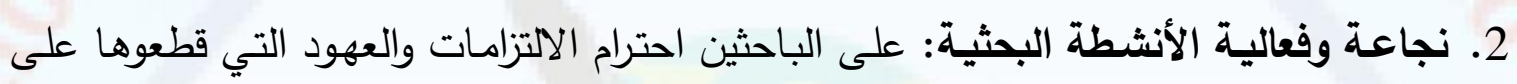

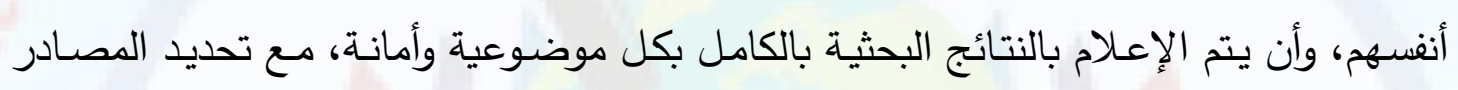

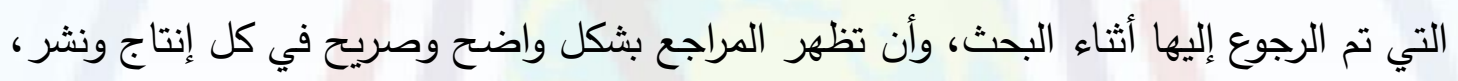
أو تواصل علمي. 3. التوافق مـع التشـريعات والأنظمـة: على جميع الباحثين الإلمام بكافة التشريعات التي تنظم الأنشطة البحثية، وضمان الامتثال لها، وخصوصا فيماً يتعلق بالبحث التجريبي.

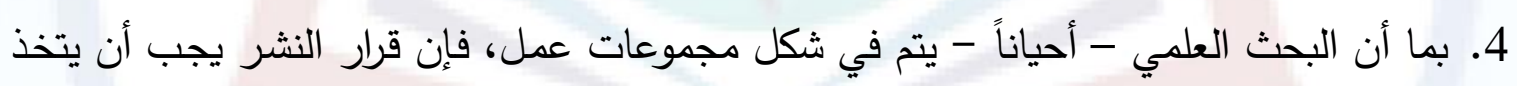

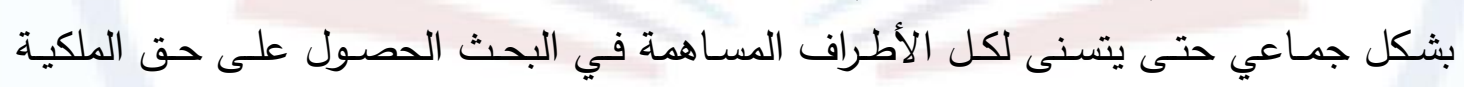
الفكرية.

5. يجب على الباحث أن يميز في بحثه بين ما يدخل في مجال خبرته العلمية، وما هو مبني على قناعاته الثخصية.

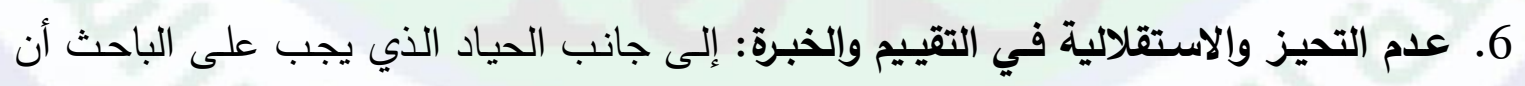

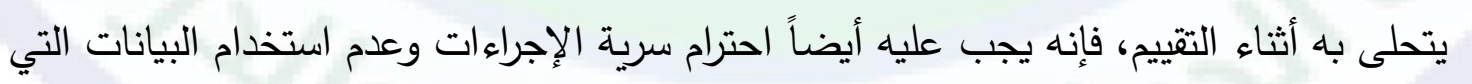
تم الحصول عليها من أدوات الدراسة إلا في أغراض البحث العلمي. لباني.

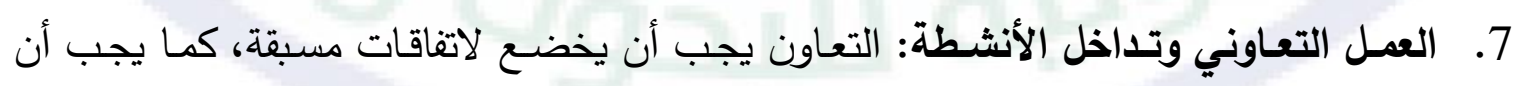

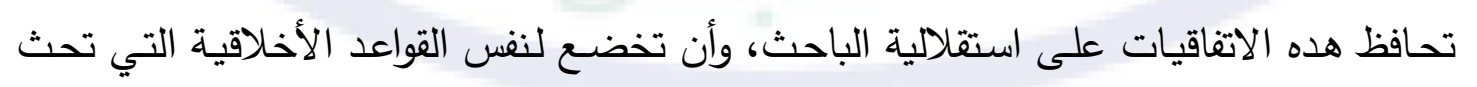
على المسؤولية الثفافية والصدق. 
ثانياً: مسؤلية الناشر : هنالك بعض الواجبات والمسؤليات يجب على ناشر البحث أو ورقة العمل

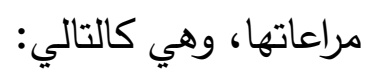

1. الأمانــة العلميـة: ينبغـي على ناشـر البحـث مراعـاة حقـوق الطبـع والاقتبـاس مـن أطروحـات

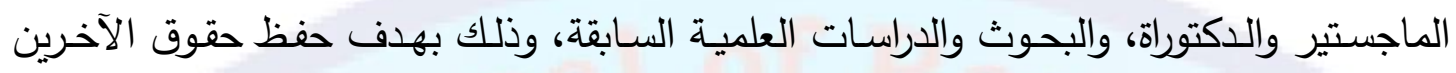

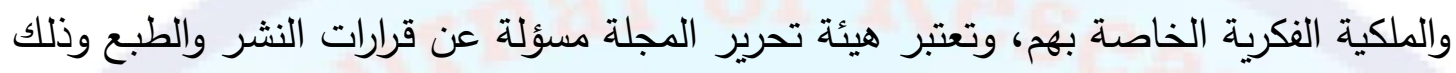
طبقاً للسياسة التي تتنهها المجلة، والمتطلبات القانونية للنشر والطبع. 2. السرية: كل البيانات والمعلومات والإحصائات الخاصـة بالباحثين سرية وهي مسؤلية كل هيئة تحرير المجلة، وكل من له علاقة بالنشر والطبح.

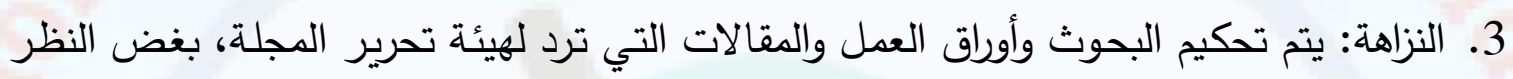
إلى جنس، أو دين الباحث، أو الانتماء ات البحون السياسية والحزبية.

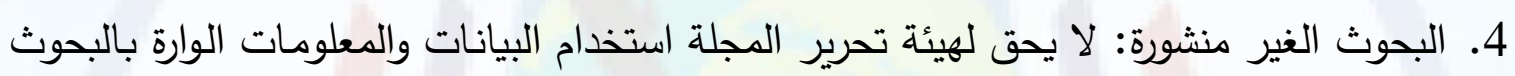

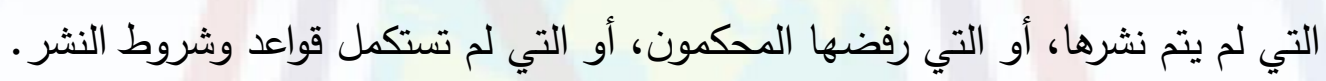

ثالثاً: مسؤلية المحكم(المراجع): التحكيم العلمي هو توظيف المنهج العلمي في تقويم البحوث المقدمة قبل نشرها وذلك من خلال

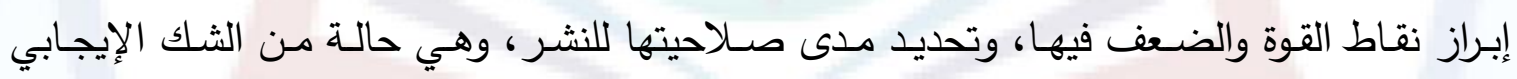

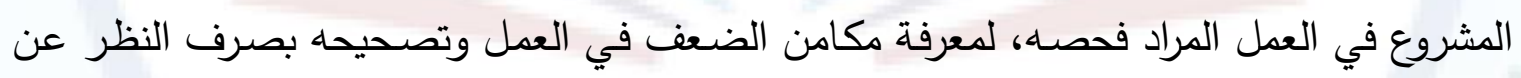

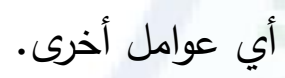

أ.فوائد التحكيم العلمي: وتكمن فوائد التحكيم العلمي، فيما يلي: 1. التقييم والنقد الدقيق لمختلف جوانب العمل العلمي لإظهار جوانب القوة التي يتمتع بها وإظهار نواحي القصور التي تعتريه.

2. إظهار مدى التزام العمل العلمي بخطوات المنهج العلمي وأساسياته، ومن ثم الحكم عليه وتقييم ما قدمه من جديد يمكن إضافته للتخصص العلمي الذي يتبعه الباحث.

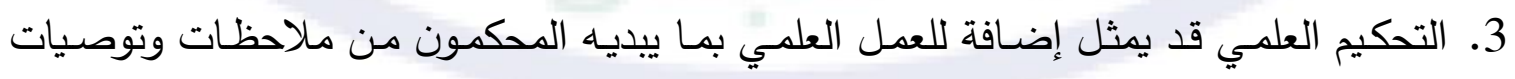
ترتفع بالعمل العلمي إذا أخذ بها الباحث.

4. التحكيم العلمي أحد أهم الجوانب الداعمة لتطور الإنتاج العلمي، حيث تعتمد أغلب المعطيات البحثية على مدى إفادة الباحثين من ملحوظات المحكمين ومقترحاتهر. 


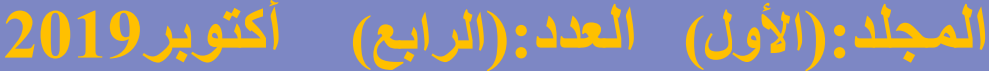

ب. أهداف التحكيم العلمي: وتتمثل أهداف التحكيم العلمي، فيما يلي: 1. وضع ضوابط ومعايير للمؤلفين في العلم بوجه عام. 2. تحسين جودة القرارات ومصداقيتها بشأن قبول النشر . 3. إيقاف البحوث العمية منخفضة الكفاءة مبكراً والارتقاء بمعايير التخصص وإرسائها. 4. تقديم تقييم عادل غير منحاز وحذر وأمين للبحث العلمي. 5. الارتقاء بالجودة العلمية للبحوث العلمية. 6. تطوير مستوى الرسائل الجامعية، والعمل على إيجاد رسائل علمية يتوافر فيها أغلب المعايير التي لابد من توافرها فيها، كالترقي إلى مصاف الرسائل العلمية العالمية. 7. تحقيق هـدف أساسـي يتعلق بطالب الدراسـات العليـا، وهـو مـنح الدرجـة العلميـة سـواء كانـت للماجستير أو الدكتوراه.

جـ معايير التحكيم العلمي: نظرًا للاختلاف في الرؤيسة والنظر إلى البحوث المحكّمـة من فاحص لآخر ، كان من الضروري تحديد مجموعة معايير وضوابط للتحكيم تضمن لهذه البحوث قدرًا مناسبًا من الجودة،كما تحمي التحكيم نفسه من الإسفاف أو التردي في هوّة الارتجال والمجازفة، أو تقديم الاعتبارات، أو المصـالح الشخصية على المصـلحة العلمية، وفي ذلك أكبر الضـرر على البحث العلمي الذي يؤمَّل منـه أن يكون سبباً رئيساً في رقي الأمـة، ووعي المجتمع، وتكمن أهمية وجود ضوابط ومعايير لتحكيم البحوث العلمية في الآتي: 1. إصدار أحكام وقرارات موضوعية على الأعمال البحثيـة صـادقة وثابتة، فبوجود هذه المعايير يقضى على الارتجال والعشوائية والرؤى الذاتية المتطرِفة في التحكيم. 2. تحقيق المساواة والعدالة والنزاهة، فهي أدوات موحدة معروفة لدى الباحثين والمحكمين وعمادات الدراسـات العليا والبحث العلمي في جامعاتنـا، وهي دعوة للباحثين إلى الإفـادة مـن المعـيير والضوابط المحدّدة في توجيه بحوثهم محتوى ومنهجاً ونتائج. 3. التخلص - نسبياً - من مواطن الضعف والتجاوزات غير البناءة التي تعاني منها عملية البحث العلمي، فدراية الباحث بأبعاد تقويم بحثه من البداية يجعله يتلافى الأخطاء الثكلية والموضوعية والمنهجية والمطبعيـة واللغويـة وغير ذلك، وتوافر هذه الضـوابط يجعل الباحثين يقومون بتقويم 
4. الحكم على البحوث العلمية والرسائل الجامعية من خـلال بيانات موضوعية كافية؛ أي توخي الحكم العـادل المنصف على الباحثين وبحوثهم، فالعدل يمثل حقاً فطريـاً لكل فرد، ومطلباً

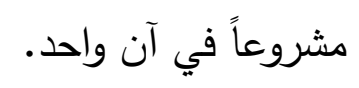

5. القضاء إلى حد مّا على تتاقض قرارات المحكمين، الناتج - غالباً - عن عدم كفاية المعايير

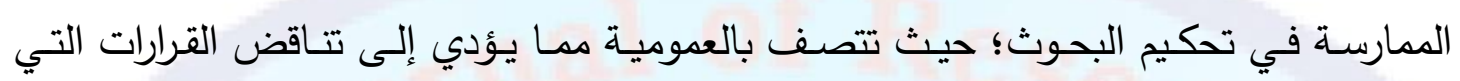

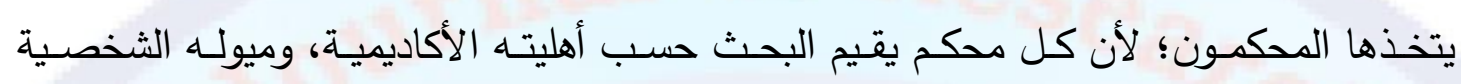

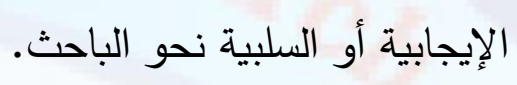

6. وجود المعايير يضمن أن تحكم البحوث والأطروحات بوضوح وبشكل دائم بناء على ما ورد في هذه المعايير ، كما يوضح مستوى ونوعية الأطروحات التي يقدمها طلاب الدراسات العليا في أي لي لئي

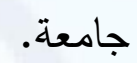

7. وجود ضوابط ومعايير للتحكيم ينعكس إيجاباً على مستوى البحث العلمي في مجاله، وعلى تطوير وتوجيه قدرات المحكمين من أعضاء هيئة التدريس وغيرهم، وتطوير قدرات الباحثين في لئي مختلف الجوانب المنهجية والعلمية والثكلية.

مما تقدّم تتبيّن ضرورة تحديد معايير وضوابط علمية وفنية يتم على ضوئها تحكيم البحوث والرسائل

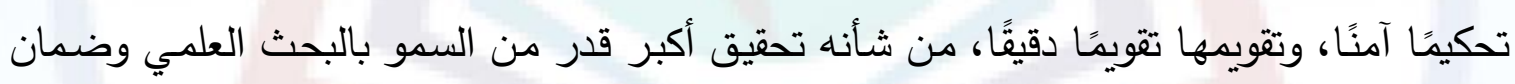

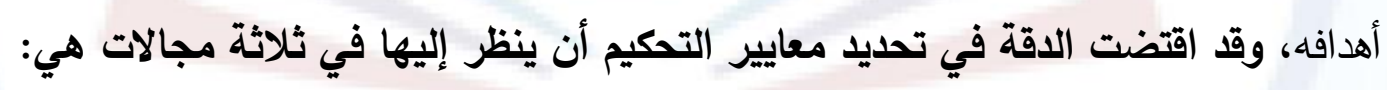

المجال الأول: معايير تحكيم البحوث العلمية.

> لابد أن يكون عنوان البحث دقيقاً واضحاً خالياً من العبارات المضللة. > وأن يتضمن البحث تعريفاً موجزاً بموضوع البحث، وأهميته، وأسباب اختياره.

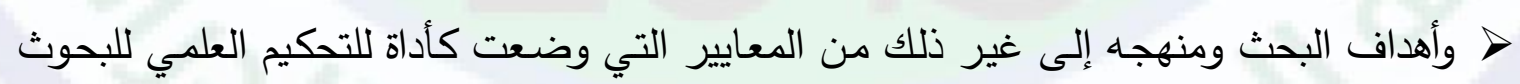
العلمية.

> فلكل من هذه الأمور معايير لابد من الاهتمام بها من قبل لجان التحكيم المناقثة لهذه الأبحاث

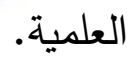

المجال الثاني: معايير تحكيم الرسائل الجامعية ومناقشتها. • ينبغي لمن يحكم الرسالة، أو يناقشها أن يعنى بتقويم الجوانب الرئيسة للرسالة. 


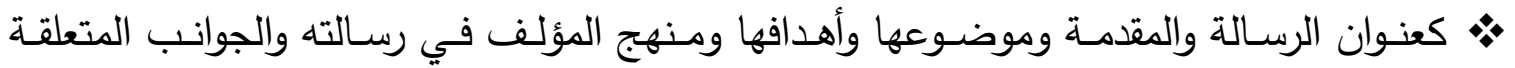

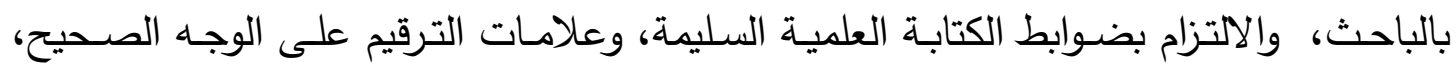
وتطبيق قواعد المنهج العلمي في النقل والاقتباس، وتتاسق الرسالة من حيث الثكل والتنظيم

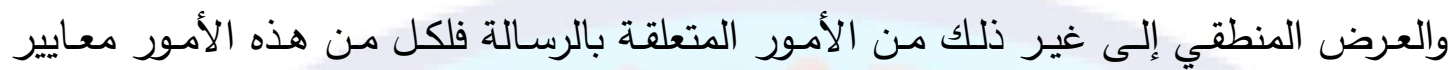
موضوعة لابد للدحكم من مراعاتها عند مناقشة الرسائل العلمية. المجال الثالث: معايير تحكيم تحقيق المخطوطات. ومسن ذلك معـايير تحكيم قيمـة النص المحقق العلميـة ونُسَخِهه ومـنهج التحقيق، ومعـايير تحكيم الإمكانات الذاتية للباحث المحقق. خامساً:ضوابط التحكيم العلمي. إن وجود ضوابط للتحكيم ينعكس إيجاباً على مستوى البحث العلمي، وعلى تطوير وتوجيه قدرات المحكمين من أعضاء هيئة التدريس وغيرهم، وتطوير . قدرات الباحثين في مختلف الجوانب المنهجية والعلمية والثكلية. فتحديد معايير وضوابط علمية وفنية يتم على ضوئها تحكيم البحوث والرسائل تحكيمًا آمنًا، وتقويمها

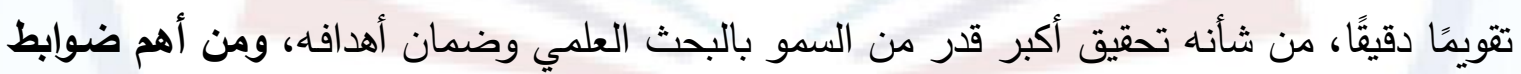
التحكيم ما يأتي:

1. على المُحكم إبداء رأيه بنزاهة ودون تحيز أثناء تحكيمه للبحث.

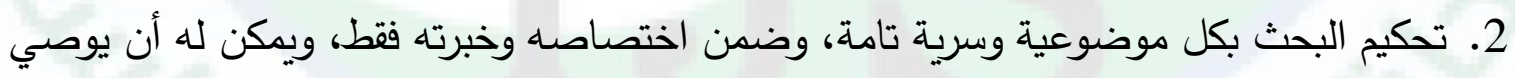
بترشيح أحد زملائه فيما ليس من اختصاصنه.

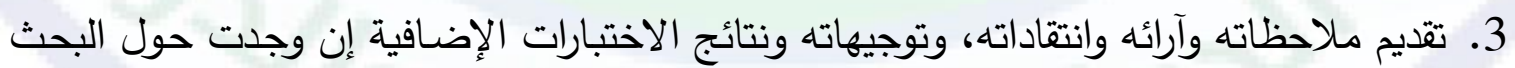
العلمي قيد التحكيم إلى الجهة طالبة التحكيم.

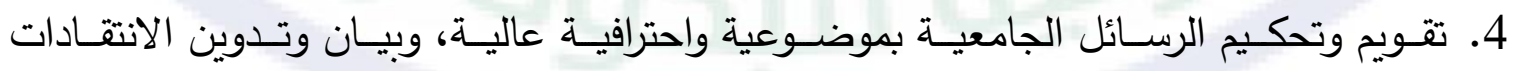
والملاحظات الواردة على الرسالة.

5. في حالة إثارة المحكم إلى الانتحال العلمي في المادة العلمية التي يقوم بتحكيمها أو وجود خلل

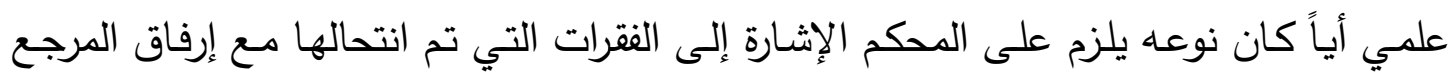




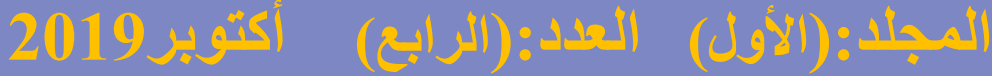

الأصلي المنتحل منه، كذلك في حالة الإشـارة إلى وجود خلل علمي أياً كان يجب عل المحكم الإشارة إليه بدقة وأمانة.

6. تحري الدقة في التمييز مـا بين الخطأ في التحرير عند ذكر المرجع في المـادة المحكمة وبين الانتحال العلمي، وبيان ما إذا كان الخطأ عن دراية وقصد أم عن سهو ونقص في خبرة صاحب

المادة المحكمة.

\section{سابعاً: أخلاقيات التّحكيم العلمي.}

يقوم المحكّم بعمل مهم ومؤثّر في عملية تقويم الرسائل، والأبحاث العلمية المقدمة لأهداف وأغراض مختلفة، وقد تكون نتيجة التحكيم قبول الأعمال المحكمة، أو ردّها بعد الحكم عليها بعدم صـلاحيتها، ومواءمتها لما قدّمت له.

ونظرًا لخطورة ما يبديه المحكّم من رأي، وتأثيره البالغ على صناعة القرار بشأن رسالة علمية، أو بحث علميّ، كان من الضروري أن يتحلّى المُحكّم بأخلاق وقيم إيجابيّة، تتمثّل في الآتي: أولاً: قيم شخصية المحكم الخُلقية والمعرفية: 1. مراقبة الله - سبحانه وتعالى. 2. إخلاص النية، والصدق في القصد، والقول، والعمل. 3. الأمانة، والنزاهة، وعدم التأثر السلبي بالعلاقات الثخصية. 4. الحلم والأناة، حتى لا يؤدي غضب المحكم أو استعجاله إلى عدم الإنصاف في الحكم. 5. العفة، والبعد عن الحرام كالرشوة الصريحة، أو المتلبّسة بالهدية. 6. المحافظـة على الأسـرار، وذلك مـن الوفـاء بالعهد الذي حـث عليـه الإسـلام، وعدم التشـهير بالباحثين، أو وصفهم بما لا يليق. 7. معرفـة ضـوابط التحكيم العلمي ومعـاييره، وتوافر الخبرة المناسبة في ممارسـة التقويم، ليتمكن المحكَّم من الحكم على البحث العلمي بثكل جيد. 8. سـعة الاطـلاع العلمي، والاهتمـام بموضـوع البحث؛ ليستطيع المحكَّم الحكم على مدى جودة البحث وأصالة مادته، وتميُّه عن غيره. 
ثانياً: القيم الخُلقية أثناء التحكيم:

1. الموضـوعية، وتعني التقويم وفق ضـوابط ومعـايير تستمد جوهرهـا من سـات البحث العلمي الصـيح، مـع التجرد عن الأهواء والأغراض الشخصـية، والبعد عن الارتجـال والمجازفـة في

$$
\text { إصدار الأحكام. }
$$

2. عدم التأثر بالوساطات والضغوط التي قد يتعرض لها المحكم.

3. الاعتذار عن مهمة التحكيم عند وجود رابطة قرابة أو صداقة مؤثرة.

4. الاعتذار عن القيام بمهمة التحكيم إذا كانت البحوث في غير تخصصهـ.

5. أن يختار الوقت المناسب لقراءة الأبحاث التي يحكمها، فـلا يكون في حالة غضب شديد، أو

حزن أو نوم أو كسل أو شدة حر أو برد، بحيث يخرج فيها عن سداد النظر واستقامة الحال.

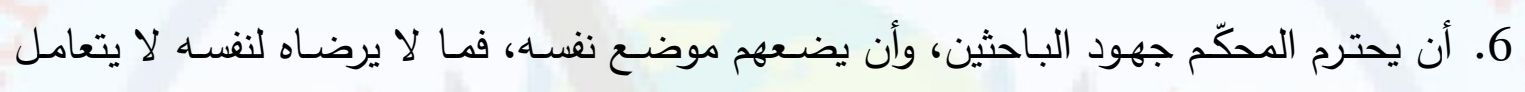
معهم باه، أو بمثله.

7. أن يتوجه المحكّم بملحوظاته إلى البحث، وليس إلى شخص الباحث.

8. عدم التأثير على الزملاء المحكمين الآخرين بما يمكن أن يجعل قراراتهم غير موضوعية، أو

غير دقيقة.

ثالثاً: القيم التي تراعى أثناء صياغة التقرير:

1. الترفّح عن استخدام الكلمات أو العبارات الجافة أو الجارحة مهما كان تقصير الباحث.

2. الهدوء وعدم الحِدّة في تقديم الملحوظات.

3. أن يثمّن المحكّم جهود الباحث باعتدال، ودون مبالغة في مدحه والثناء عليه وإطرائه. 4. أن يكون النقد الموجّه إلى الرسالة أو البحث المحكّم نقدًا بنّاءً.

5. عدم البدء بالنقد، وإنما بالإشادة بجهد الباحث، ثم إيضاح جوانب النقص والضعف. 6. الالتزام باللغة الصحيحة الفصيحة في كتابة التقرير . 7. الوقوف عند كل ملحوظة بمقدار ما لها من الأهمية.

8. احترام آراء الباحث، وعدم مصادرتها بأي لون من ألوان المصادرة.

9. عدم إصدار الحكم بإجازة البحث أو ردّه إلا بعد التثبت والتروِي.

نصسائح وتوجيهات لطالب التحكيم ( المحكَّم لـه) هذه بعض النصـائح والتوجيهات لطالب التحكيم

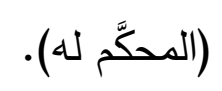




\section{المبأد:(الأول) العدد:(الرابع) أكثوبر2019}

إن ما ترغبون في تحصيله هو هدف وأمل نبيل يتمناه الكثير من الطلبة المتخرِجين من مرحلة التدرّج

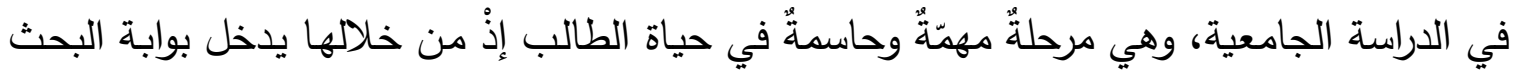

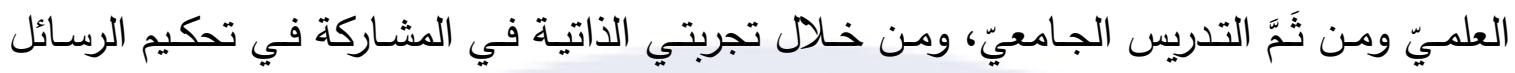
والأبحاث العلميـة ومن خـلال تدريسي في الدراسـات العليا ولقائي بالعديد من الباحثين ظهرت لي لئي بعض الأفكار والرؤى أوجزها على شكل نصائح وتوجيهات ومنها: أولاً: نصائح قبل البدء في كتابة البحث أو الرسالة: إخلاص النية لله تعالى وتتبعها حتى يكتب الله لك الأجر في ذلك. الاستعانة بالله في عامة ما تكتب بل في عامة أمورك، فمن توكل على الله أعانه. وضع الهدف الذي ترغب من خلاله الحصول على درجة علمية.

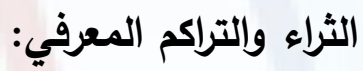

مما أنصح به أيضاً أن يكون لدى الطالب ثراء وتراكم معرفي ويأتي هذا في مجال التخصص أساسًا

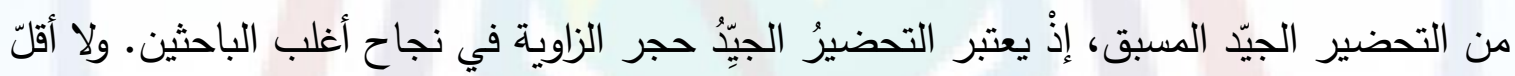

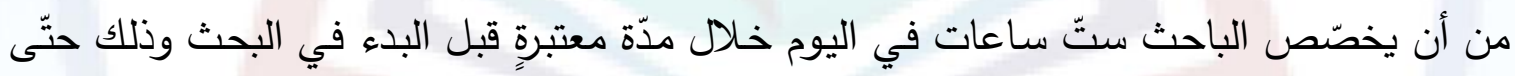
يحصل لديه التراكم المعرفي المطلوب.

وقد أثبتت الملاحظات الميدانية والتجارب الواقعية أنّ أغلب الحاصلين على درجات علمية يتميّزون بثراءٍ معرفيّ معتبرٍ يستندُ أساسًا إلى تحضيرٍ جيٍٍّ. على الباحث اختيار أفضل الكتب المؤلفة في مجال ما يبحث فيه وذلك من خلال توجيه الأساتذة وملاحظته الذاتية.

ينبغي عليه أيضاً الاطلاع على الدراسات الحديثة المنشورة في الدوريات العامة والمتخصّصة؛ فكثيرًا ما تكون مواضيع البحوث مرتبطة بإشكالات متعلقة بموضوع البحث الذي يقوم بها. 


\section{المجلد:(الأول) العدد:(الرابع) أكتوبر2019}

الاستدلال العلمي على الآراء والأفكار : - الع

فجديرٌ بالباحث أن يبني أفكار موضوعه الأساسية على أدلة نقلية، وعقلية، أو نصوص ومقولات

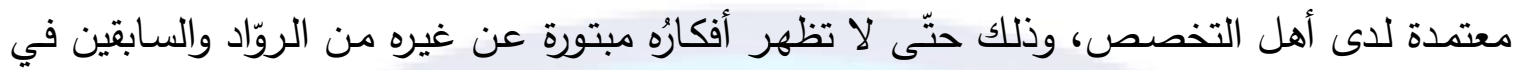
الحقل المعرفي الذي يهتم به.

الدقة اللغويـة: وذلك باستخدام عباراتٍ موجزة معبّرة عن المعنى المراد من غير إطالةٍ أو تكرارِ أو

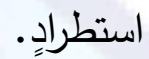

اللفة العلمية: وهي التي تستخدم اصطلاحات التخصص، وتتبنّى الموضوعية في عرض الأفكار

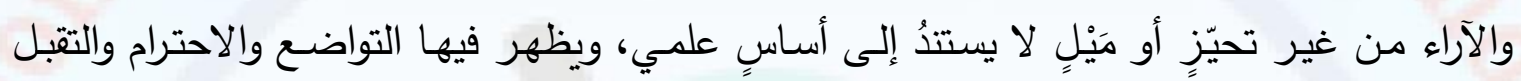

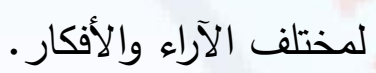


حقوق الباحث وحقوق المجلة.

أولاً: حقوق الباحث (الناشر) العلمية: تخضع جميع البحوث والدراسات المنشورة في المجلة الدولية للبحوث والدراسات (IJS) للتحكيم من الدئل قبل متخصصين من ذوي الخبرة البحثية والمكانة العلمية المتميزة. تحرص المجلة الدولية للبحوث والدراسات (IJS) على أن رتبة الدحكم العلمية أعلى من رتبة الباحث

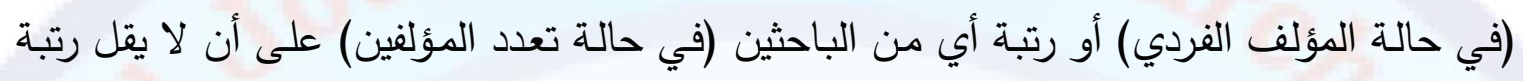

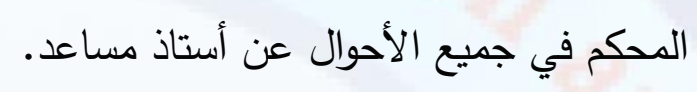

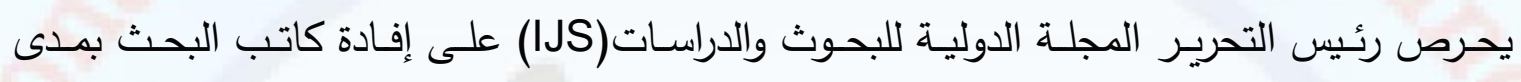

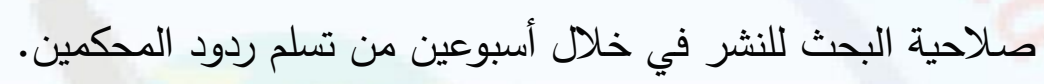

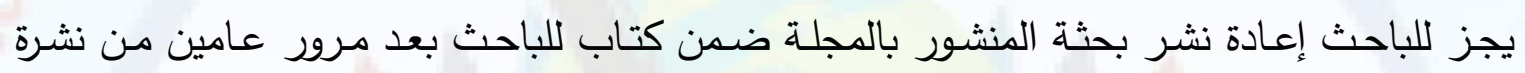

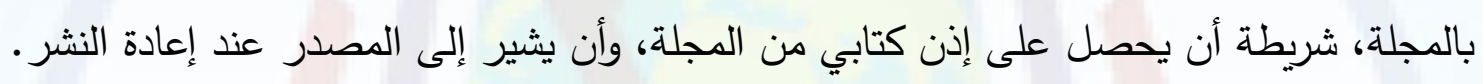

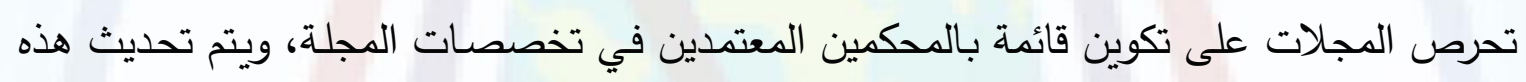

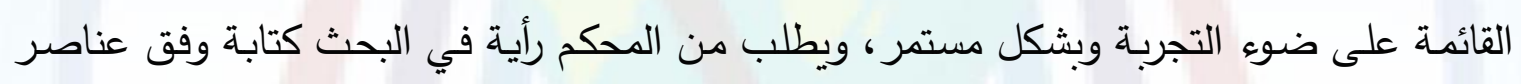
محددة، تتضمن على سبيل المثال: 1. أصالة البحث ومدى إسهامة المعرفي في مجال التخصص.

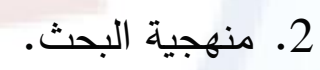
3. المصادر والحواشي. 4. سلامة التكوين واللغة والاستنتاجات، ويطلب إلية في نهاية تقييمه العام إبداء الرأي في مدى البـ صلاحية البحث للنشر.

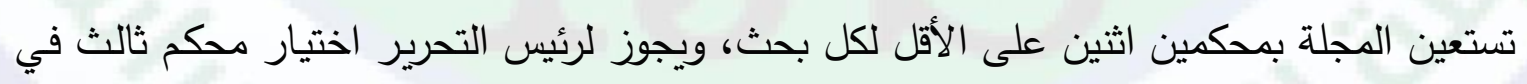

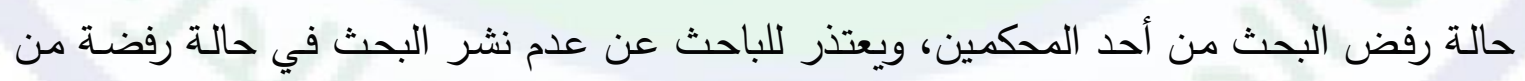

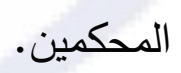
ثانياً: حقوق المجلة، ومن هذه الحقوق، ما يلي:

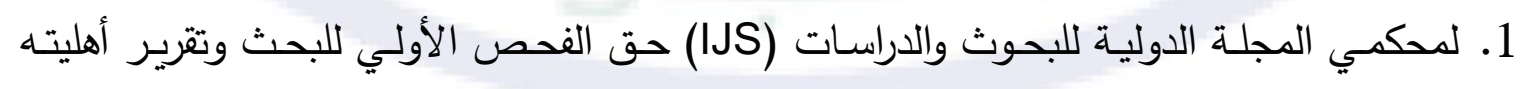

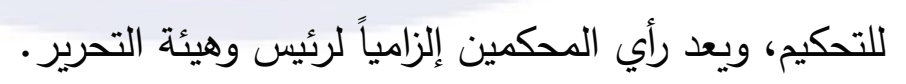

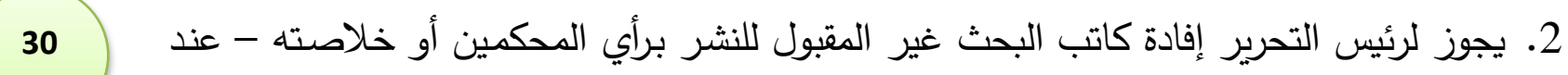

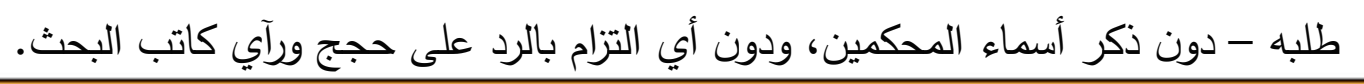

International Journal of Research and Studies (ijs) It is issued by the Excellence Pioneers Academy 
3. يعتبر البحث في حكم الإلغاء إذا تأخر الباحث عن إجراء التعديلا المطلوبة على البحث لمدة

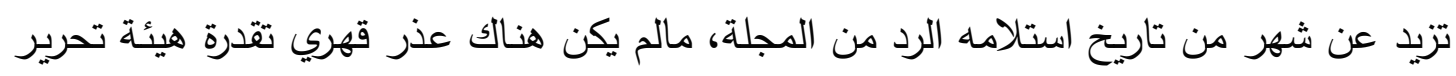
المجلة.

4. ل ايجوز نشر البحث في مجلة علمية أخرى بعد إقرار نشرة في الدجلة الدولية للبحوث والدراسات

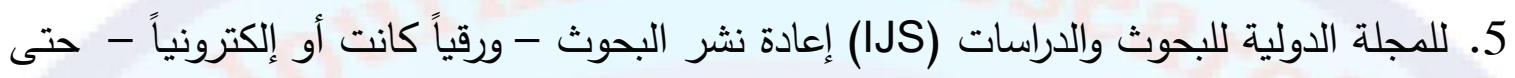

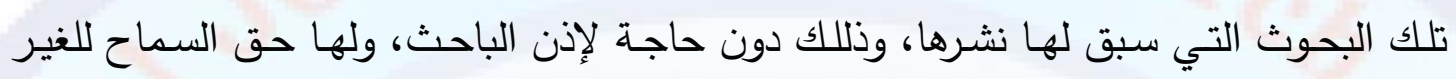

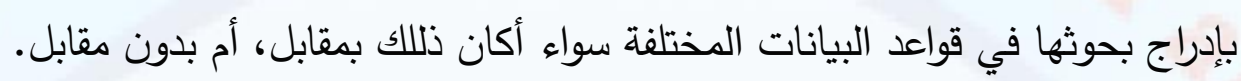

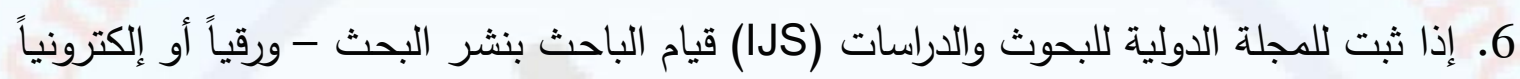

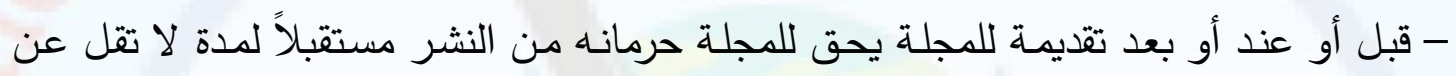

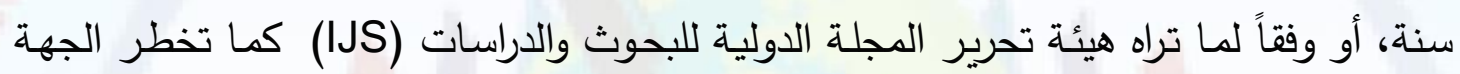
التابعة له بذلك. 7. إذا لم يلتزم الباحث بإجراء التعديلات المطلوبة من قبل المحكمين والمجلة أو قام بسحب البحث

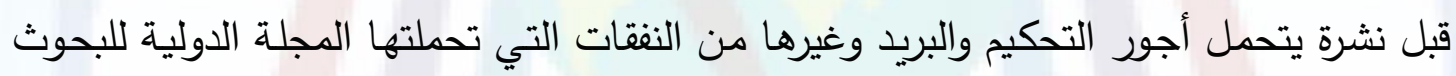
والدراسات (IJS). 


\section{المجلة الدولية للبحوث والدراسات (IJS).}

الحمد الله الذي خلق فسـى، وقدر فهدى؛ وخلق الإنسـان؛ وعلمـه البيان، ونصـلي ونسلم على المبعوث رحمـة للعـالمين، والمعلم الأول لهذه الأمسة؛ رسولنا الكريم، حمح صـلى الله عليـه وعلى آله 666666666666662 وصحبه،

وصلنا إلى العدد الرابع - بغضل الله - من المجلة الدولية للبحوث والدراسات (IJS) والتي تصدرها أكاديمية رواد التميز للتدريب والاستشارات والتتمية البشرية، بين يديك مع مطلع شهر أكتوبر، نسأل الله عز وجـل أن يمنحنـا الأمـن والأمـان والسـلام والاستقرار ، ويعينتـا على طاعته، والتقرب إليـه، والازدياد من العلم النافع.

كمـا أننـي أتوجـه بجزيـل الثكر وبـالغ الامتنـان؛ لكل مـن سـاهموا في إخراج العدد؛ مـن الباحثات والباحثين؛ من جمهورية مصر العربية، والمملكة العربية السعودية، والثكر موصول لكل المحكمين والإداريين؛ لجهودهم المتميزة، سائلاً الله أن يجزيهم خير الجزاء. وتؤكد وتكرر هيئة تحريـر المجلـة الدعوة لجميع الباحثين والباحثات؛ مؤكدين أن المجلـة-وكمـا كانت- ستبقى قبلة لجميع الباحثين والأكاديمين؛ ونرحب بالأفكار الإبتكاريـة والإبداعية الخلاقة، كما نشـجع البحوث الفرديـة والجماعيـة؛ سـواء منهـا النظريـة، أو الميدانيـة، وكل مـا مـن شـأنه الارتقـاء بالمستوى التعليمي، والتربوي والنفسي، والذي يعد السبيل الأمثل لمعالجة المشكلات وتجاوز العقبات التي تحـول دون نهضــة أمتتـا، سـائلين الله أن يوفق الجميـع، وأن لا يؤاخذنا بـنوبنا ولا بمـا فعلـه السفهاء منا، وأن يدفع عن عباده الموحدين كل سوء ومكروه. وتؤكد هيئة تحرير المجلة لقرائها بأنها لا تزال تسير على النهج محافظة على انتقاء البحوث التي تتشرها، وهي بحوث جيدة ومتميزة يقوم المحكمون بإبداء آرائهم ومقترحاتهم ولا يتم نشرها إلا بعد

\section{International Journal of Research and Studies (ijs) It is issued by the Excellence Pioneers Academy}




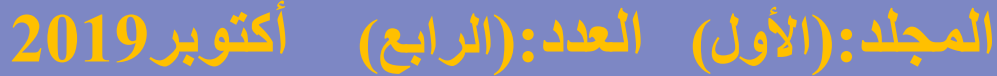

أن يقوم الباحث بإصـلاح وتعديل البحث وفقاً لمـا أبداه المحكمون من آراء لتجويد البحوث التي تنشرها المجلة الدولية للبحوث والدراسات (IJS).

وتأسيسـاً على ماسبق فإن هيئة تحرير المجلـة تستثر هذه الفرصـة وتدعو كل الزملاء الباحثين المتخصصين في فروع العلوم الإنسانية عامة، وفروع العلوم التربوية خاصـة، لنشر بحوثهم وإنتاجهم العلمي بالمجلة الدولية للبحوث والدراسات (IJS). وذلك طبقا لقواعد النشر المعلنة على موقع المجلة، ونعاهد الله أن نكون عوناً لكل باحث جاد مجتهد يرغب في نشر نتاج فكره وحصاد جهده، وأن نكون معين علم لكل باحث عن المعرفة التي تتصل بمجالات عمل المجلة، حتى نساهم مساهمة بناءة في خدمة العلم والعلماء. وكلنا أمل وثقة بالله أن تكبر المجلة الدولية للبحوث والدراسات(IJS) مع الأيام بفضل الله أولاً، ثم تفاعلكم معنا قراءً وكتابًا، خدمةً للبحث العلمي، ونحن في انتظار مشاركاتكم واقتراحاتكم على

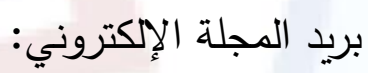
للتو اصل: ميل: osama.elshrief@yahoo.com فون وواتس:(0096658380991) - 00201090854422-0011 50977347 
يسعني باسم هيئة تحرير المجلة الدولية للبحوث والدراسات (IJS) أن أقدم لأحبتنا الباحثين الكرام، جمهور المجلـة العـد (4) مـن المجلد (4) أكتوبر (2019) وتضــن (5) أبحـاث قيمـة؛ تنوعت موضوعاتها لتشمل الإدارة والمناهج وطرق التدريس، والأنثطة المدرسية، منها أربعة بحوث باللغة العربية، والبحث الخامس باللغة الفرنسية. وقد تضمن العدد الثالث للمجلة الدولية للبحوث والدراسا(IJS) خمسة بحوث متنوعة، تناولت موضوعات متتوعة، الموضوع الأول، بعنوان: معوقات ممارسة الأنثطة المدرسية، دراسـة ميدانية من وجهة نظر طالبات مرحلة التعليم المتوسط بمحافظة صبيا، والموضوع الثاني، بعنوان: عوامل ثورة 25 يناير وأهدافها وأهم تداعياتها على البحث العلمي التربوي (دراسة تحليلية). و الموضـوع الثالـث: بعنـوان: إعجـاز القـرآن في الحــيث عـن لغـة الطيـر والحيـوان، و الموضوع الرابع، بعنوان: واقع العمل التطوعي لطلبة السنة الأولى المشتركة وتصور مقترح The Reality of Voluntary work for students the Common First (تطويره (Year Students, and suggested proposal for its development الخـامس، بعنوان: Emploi de la Conscience graphophonologique pour le Développement de la Compréhension Orale \& pour le Renforcement des Rapports Phonèmes / Graphèmes en FLÉ chez les Maxi-Débutants

وتود هيئة تحرير المجلة أن تتقدم بجيل الثكر والعرفـان للبـاحثين الذين اختاروا المجلة الدولية للبحوث و الدراسات (IJS) لتكون و عاءً لنشر بحوثهم و إنتاجهم العلمي، وأن هيئة التحرير بالمجلة تولي اهتماماً كبير اً بكل ما يرد إليها من ملاحظات أو تعليقات، وتضع كل ما يرد إليها من مقترحات نصب أعينه، وذللك سعياً منها لدراستها، واستثمار ها في تطوير المجلة وتجويدها. وفقنا الله لما فيه النفع والرقي بالبحث العلمي.

\section{International Journal of Research and Studies (ijs)}


وقد اشتمل المجلا: (الأول) العدد: (الرابع) أكتوبر 2019 على عدد من البحوث والدراسـات،

\begin{tabular}{|c|c|c|c|}
\hline \multicolumn{4}{|c|}{ محتويات العدد الرابع (أكتوبر 2019). } \\
\hline الصفحة & اسم الباحث & عنوان البحث & 5 \\
\hline $36^{-1}$ & \multicolumn{3}{|c|}{ افتتاحية العدد الرابع (أكتوبر 2019). } \\
\hline & 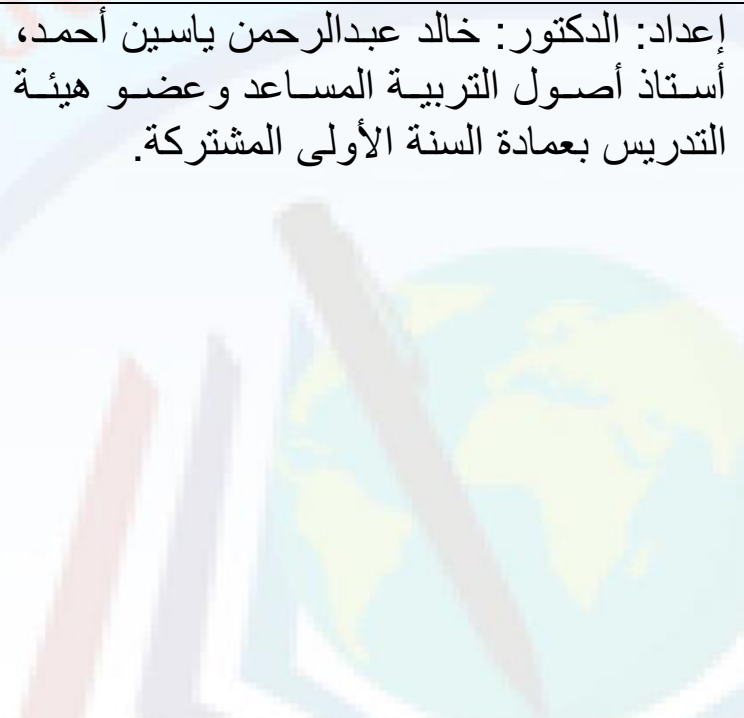 & 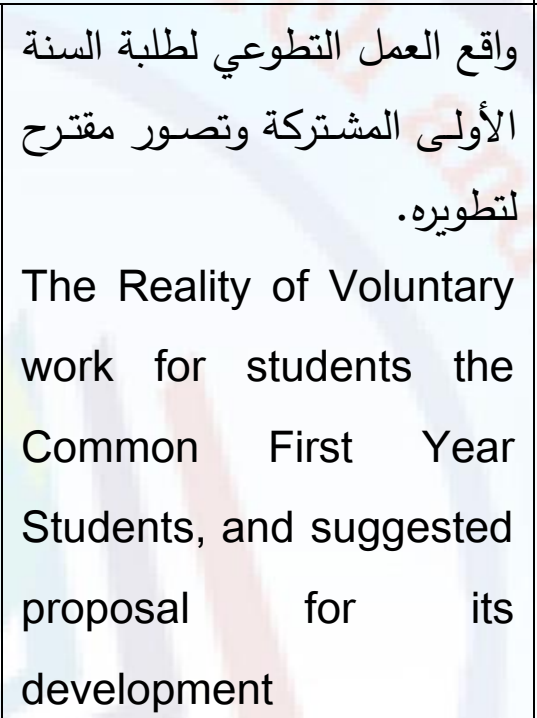 & 1 \\
\hline $51-25$ & 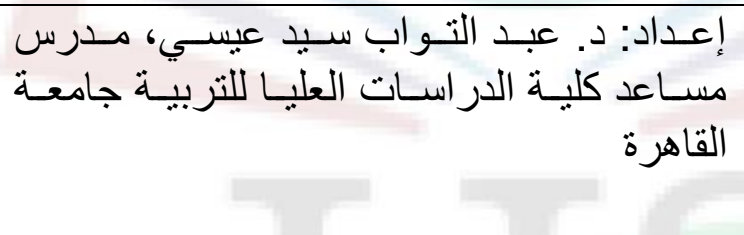 & |تحليلية). & 2 \\
\hline $144-52$ & $\begin{array}{l}\text { Étude Présentée par: Dr. Abdel } \\
\text { Nasser Chérif Mohammad. } \\
\text { Professeur-adjoint de la Didactique } \\
\text { de FLE. }\end{array}$ & 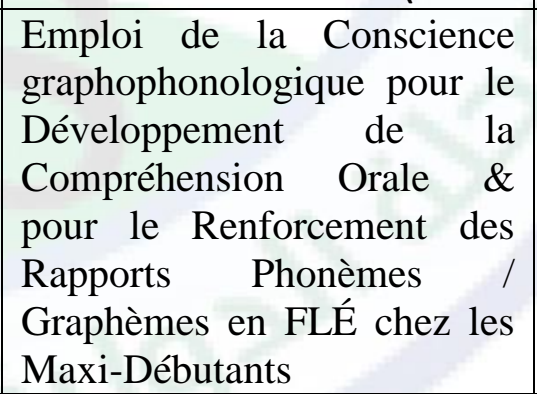 & 3 \\
\hline $188-145$ & 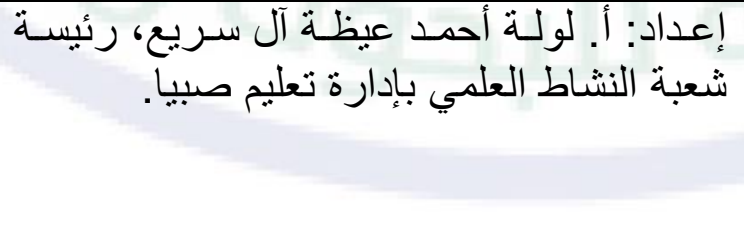 & 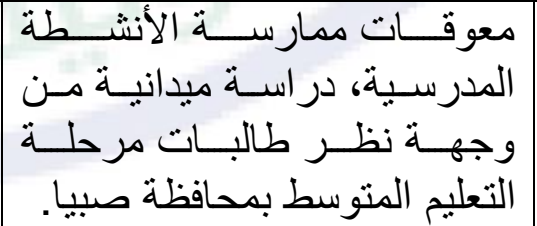 & 4 \\
\hline 194-189 & 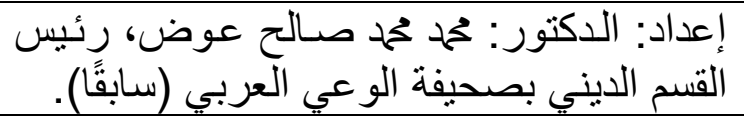 & 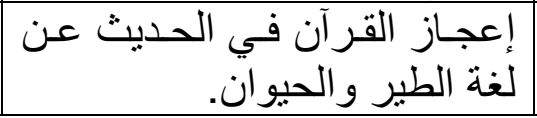 & 5 \\
\hline
\end{tabular}


الاشتراكات السنوية في عضوية المجلة الدولية للبحوث والدراسات (IJS).

\begin{tabular}{|c|c|c|c|}
\hline مدة الاشتر اك & الدول العربية & مصر & نوع الاشتراك \\
\hline \multirow[t]{2}{*}{ سنة } & 50 دولار & 150 جنيه & أفَراد \\
\hline & 150 دولار & 350جنيه & مؤسسات \\
\hline \multirow[t]{2}{*}{ سنتان } & 85دولار & 250جنيه & أفُراد \\
\hline & 280 دولار & 300جنيه & مؤسسات \\
\hline
\end{tabular}

والله من وراء القصد وهو يهدي السبيل.

$$
\text { والله ولي التوفيق والنجاح. }
$$

هيئة تحرير هيئة تحرير الدجلة الدولية للبحوث والدراسات(IJS).

$$
\text { رئيس التحرير. }
$$

أ.د. نجوى يوسف جمال الدين.

أستاذ متفرغ بقسم أصول التربية.

وكيل الكلية لشئون خدمة المجتمع وتتمية البيئة سابقاً.

كلية الدراسات العليا للتربية، جامعة القاهرة

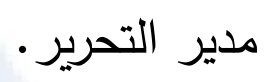

أ.م.د. ممدوح عواد مفلح العنزي.

أستاذ أصول التربية المساعد.

مستشار وكيل جامعة تبوك للفروع.

\section{نائب رئيس التحرير.}

أ.م.د. محمود عبد المجيد رشيد عساف.

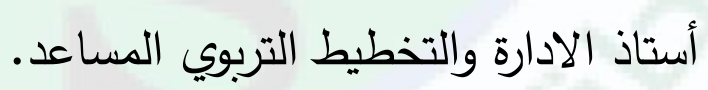

وزارة التربية والتعليم الفلسطينية.

\section{رئيس مجلس الإدارة.}

أ.م.د. أسامة عبد الغفار الثريف.

أستاذ الإدارة التربوية المساعد، جامعة تبوك والملك سعود وطيبة سابقاً.

عميد الأكاديمية، ورئيس مجلس الإدارة.

International Journal of Research and Studies (ijs)

It is issued by the Excellence Pioneers Academy 


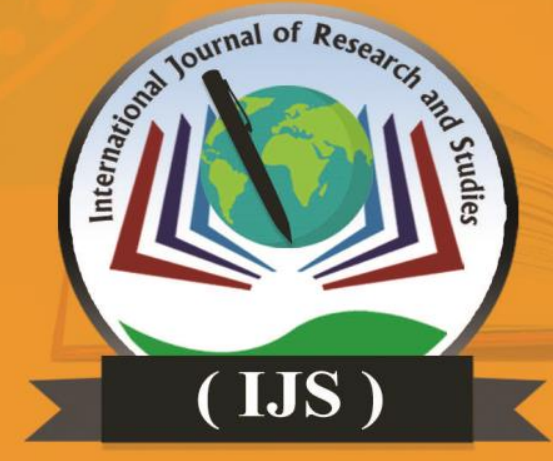

International Journal of Research and Studies

$$
\text { ( IJS ) }
$$

